Supporting information:

\title{
Secondary formation and impacts of gaseous nitro-phenolic compounds in the continental outflow observed at a background site in South China
}

Yi Chen ${ }^{1,2}$, Penggang Zheng ${ }^{1,2}$, Zhe Wang ${ }^{1,}{ }^{*}$, Wei Pu ${ }^{2}$, Yan Tan ${ }^{2}$, Chuan Yu ${ }^{2}$, Men Xia ${ }^{2}$, Weihao Wang $^{2}$, Jia Guo ${ }^{3}$, Dandan Huang ${ }^{4}$, Chao Yan ${ }^{5}$, Wei Nie ${ }^{6}$, Zhenhao Ling ${ }^{7}$, Qi Chen ${ }^{8}$, Shuncheng Lee 2, Tao Wang $^{2}$

${ }^{1}$ Division of Environment and Sustainability, The Hong Kong University of Science and Technology, Hong Kong SAR, 999077, China

2 Department of Civil and Environmental Engineering, The Hong Kong Polytechnic University, Hong Kong SAR, 999077, China

${ }^{3}$ Research Center for Eco-Environmental Sciences, Chinese Academy of Sciences, Beijing 100085, China

${ }^{4}$ State Environmental Protection Key Laboratory of Formation and Prevention of Urban Air Pollution Complex, Shanghai Academy of Environmental Sciences, Shanghai, 200233, China

${ }^{5}$ Institute for Atmospheric and Earth System Research / Physics, Faculty of Science, University of Helsinki, Helsinki, 00014, Finland

${ }^{6}$ Joint International Research Laboratory of Atmospheric and Earth System Research, School of Atmospheric Sciences, Nanjing University, Nanjing, 210023, China.

${ }^{7}$ School of Atmospheric Sciences, Sun Yat-sen University, Zhuhai, 519000, China

${ }^{8}$ State Key Joint Laboratory of Environmental Simulation and Pollution Control, BIC-ESAT and IJRC, College of Environmental Sciences and Engineering, Peking University, Beijing, 100871, China

Number of pages: 38

Figures: Figure S1-S22

Schemes: Scheme S1-S2

Tables: Table S1-S2 
Figure S1. The detail location and surrounding topography of the supersite.

Figure S2. High-resolution peak fitting.

Figure S3. The mass spectra measured by Tof-CIMS when 4-nitrophenol (a) and 2-nitrophenol (b) was introduced; the calibration result of 4-nitrophenol (c); isotopic analysis of Cl-NPs (d)

Figure S4. Meteorological parameters, wind direction, $\mathrm{PM}_{2.5}$, concentration of $\mathrm{SO}_{2}$ and $\mathrm{NH}_{3}$ during campaigns.

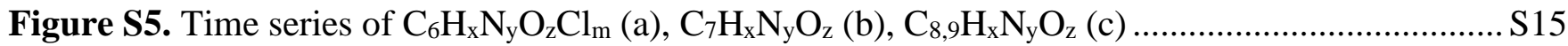

Figure S6. Correlation coefficients among different compounds during phase 1 and phase 2............ S16

Figure S7. Cluster groups of 72-h backward trajectory of air masses arriving at the observation site simulated using the HYSPLIT model.

Figure S8. Diurnal pattern of individual mono-NP (a), di-NP (b), and Cl-NP (c). S18

Figure S9. Correlations between levoglucosan and detected NPs in different clusters during the two phases measurements.

Figure S10. Correlations between CO and detected NPs in different clusters during the two phases measurements. S20

Figure S11. The fraction of secondary formation $\left(\right.$ Fraction $_{\text {sf }}$ ) of mono-NPs (a), di-NPs (b) and Cl-NPs (c) calculated with levoglucosan and $\mathrm{CO}$ tracer method in phase 1 and phase 2 S21

Figure S12. Time series of $\Delta \mathrm{O}_{3}$ and $\Delta$ nitrophenol at daytime $\mathrm{S} 22$

Figure S13. Correlations between $\Delta \mathrm{O}_{3}$ and $\Delta$ nitrophenols at daytime during 11-26 November 2018 . S23

Figure S14. The relationship of $\mathrm{C}_{6} \mathrm{H}_{5} \mathrm{NO}_{3}, \mathrm{C}_{7} \mathrm{H}_{7} \mathrm{NO}_{3}, \mathrm{C}_{8} \mathrm{H}_{9} \mathrm{NO}_{3}$ with related aromatics and $\mathrm{NO}_{2}$ concentration bins in the daytime. 
Figure S15. The relationship of $\mathrm{C}_{6} \mathrm{H}_{4} \mathrm{~N}_{2} \mathrm{O}_{5}, \mathrm{C}_{7} \mathrm{H}_{6} \mathrm{~N}_{2} \mathrm{O}_{5}$ and $\mathrm{C}_{8} \mathrm{H}_{8} \mathrm{~N}_{2} \mathrm{O}_{5}$ with their related mono-NPs, $\mathrm{NO}_{2}$ and $\mathrm{NO}_{3} \bullet$ at nighttime.

Figure S16. The concentration distribution of di-NPs (a) and Cl-NPs (b) as a function of the concentration of $\mathrm{NO}_{2}$ and colored with $\mathrm{NO}_{3} \bullet$ concentration. S26

Figure S17. The fitted result of transformation coefficient for $\mathrm{C}_{6} \mathrm{H}_{4} \mathrm{~N}_{2} \mathrm{O}_{5}, \mathrm{C}_{7} \mathrm{H}_{6} \mathrm{~N}_{2} \mathrm{O}_{5}$ and $\mathrm{C}_{8} \mathrm{H}_{8} \mathrm{~N}_{2} \mathrm{O}_{5}$. S26

Scheme S1. The formation and consumption mechanisms for $\mathrm{C}_{6} \mathrm{H}_{5} \mathrm{NO}_{3}$ and $\mathrm{C}_{6} \mathrm{H}_{4} \mathrm{~N}_{2} \mathrm{O}_{5}$...........

Scheme S2. The formation and consumption mechanisms for $\mathrm{C}_{7} \mathrm{H}_{7} \mathrm{NO}_{3}$ and $\mathrm{C}_{7} \mathrm{H}_{6} \mathrm{~N}_{2} \mathrm{O}_{5}$ S28

Figure S18. The comparison of model simulated $\mathrm{C}_{6} \mathrm{H}_{5} \mathrm{NO}_{3}$ to the observation and secondary fractions calculated $\mathrm{C} 6 \mathrm{H} 5 \mathrm{NO} 3$ (a), budget of $\mathrm{C}_{6} \mathrm{H}_{5} \mathrm{NO}_{3}$ (b), diurnal variation of $\mathrm{C}_{6} \mathrm{H}_{5} \mathrm{O}$ and $\mathrm{NO}_{2}$ (c), budget of $\mathrm{C}_{6} \mathrm{H}_{5} \mathrm{O}(\mathrm{d})$ and diurnal variation of phenol and $\mathrm{NO}_{3}$ radical (e).

Figure S19. The time series of observed and simulated $\mathrm{C}_{7} \mathrm{H}_{7} \mathrm{NO}_{3}$ (a), and diurnal variation of cresol (b).

Figure S20. The time series of observed and simulated $\mathrm{C}_{6} \mathrm{H}_{4} \mathrm{~N}_{2} \mathrm{O}_{5}(\mathrm{a})$, and diurnal variation of NPHEN1O (b). S30

Figure 21. The time series of observed and simulated $\mathrm{C}_{7} \mathrm{H}_{6} \mathrm{~N}_{2} \mathrm{O}_{5}$ (a), and the simulated budget of $\mathrm{C}_{7} \mathrm{H}_{6} \mathrm{~N}_{2} \mathrm{O}_{5}$ (b), diurnal variation of NCRES1O (c), and budget of NCRES1O (d) S31

Figure S22. The production rate of HONO from the heterogeneous reaction of $\mathrm{NO}_{2}$ on aerosol (a), the light-enhancing heterogeneous reaction of $\mathrm{NO}_{2}$ on aerosol (b), the homogeneous reaction $\mathrm{OH}+\mathrm{NO}(\mathrm{c})$, the photolysis of particle nitrate (d). S32

Table S1. The summary of NPs concentrations measured at Cape D'aguilar .................................. S33

Table S2. Average concentration of compounds input into model. S34

Reference S35 


\section{Experimental methods}

\section{HR-Tof-CIMS settings and calibrations}

A nitrated-based chemical ionization time-of-flight mass spectrometer $\left(\mathrm{NO}_{3}{ }^{-}\right.$-ToF-CIMS; Aerodyne Research, Inc.) was utilized to measure the NPs in this study. The ToF-CIMS consists of a chemical ionization source with nitric acid $\left(\mathrm{HNO}_{3}\right)$ as reagent ions, and a high-resolution atmospheric pressure interface time-of-flight mass spectrometer. Detailed information about the instrumentation of ToF-CIMS has been reported previously ${ }^{1,2}$. Briefly, the ambient air was pumped through a $2.5 \mathrm{~m}$ electro-polished stainless steel sample inlet with a flow of $10 \mathrm{~L} / \mathrm{min}$ into the chemical ionization chamber. $\mathrm{A} \mathrm{HNO}_{3}$ stream $(5 \mathrm{~mL} / \mathrm{min})$ mixed with sheath flow of zero air $(20 \mathrm{~L} / \mathrm{min})$ was exposed to soft X-ray radiation to generate primary ions, $\left(\mathrm{HNO}_{3}\right)_{\mathrm{n}} \mathrm{NO}_{3}{ }^{-}(\mathrm{n}=0,1,2)$. The $\left(\mathrm{HNO}_{3}\right)_{\mathrm{n}} \mathrm{NO}_{3}{ }^{-}$stream flowed through the outer layer of the coaxial laminar flow reactor to mix with sample air in the central layer of the coaxial laminar flow reactor. Once neutral compounds $(\mathrm{M})$ in ambient air was mixed with $\left(\mathrm{HNO}_{3}\right)_{\mathrm{n}} \mathrm{NO}_{3}^{-}, \mathrm{M}\left(\mathrm{HNO}_{3}\right)_{\mathrm{nNO}} \mathrm{NO}^{-}(\mathrm{n}=0,1,2)$ and deprotonated ions of $\mathrm{M}$ could be generated. The most abundant form of NPs detected by Tof-CIMS was $\mathrm{MNO}_{3}{ }^{-}$, followed by $\mathrm{MHNO}_{3} \mathrm{NO}_{3}{ }^{-}$and deprotonated ions of $\mathrm{M}$ in turn. Then, the ions passed through a $300 \mu \mathrm{m}$ critical orifice with a flow of $0.8 \mathrm{~L} / \mathrm{min}$ into the mass spectrometer and detected by the analyzer. The voltages in the chemical ionization chamber and API-TOF was tuned to maximize the sensitivity, mass resolution and keep good peak shape at the same time. The data were acquired at $1 \mathrm{~Hz}$ time resolution.

The obtained data were analyzed with Tofwerk software (version 3.2.0, Aerodyne Research, Inc. and Tofwerk AG) based on Igor Pro (Wavemetrics). The original data was pre-averaged into 10-min for further analysis. The following steps were performed to quantify the concentrations of the detected NPs. First, mass calibration was performed with $61.9884\left(\mathrm{NO}_{3}{ }^{-}\right), 124.9840\left(\mathrm{HNO}_{3} \mathrm{NO}_{3}{ }^{-}\right), 187.9797\left(\left(\mathrm{HNO}_{3}\right)_{2} \mathrm{NO}_{3}{ }^{-}\right)$, $201.0153\left(\mathrm{C}_{6} \mathrm{H}_{5} \mathrm{NO}_{3}\left(\mathrm{NO}_{3}\right)^{-}\right)$to ensure accuracy of mass detection within $5 \mathrm{ppm}$. The average mass resolution of Tof-CIMS for $\mathrm{m} / \mathrm{q}>200$ during the whole campaign was 5200 . Then the high-resolution peak fitting was conducted to identify the detected ions. Figure S2 provided the peak fitting results of observed NPs, and most of the detected NPs were the dominant components for the unit mass peak. By assuming the same ionization efficiency of different NPs, a mass-dependent transmission method was used to correct 
the intensity of different ions, following the approach described by Heinritzi et al. ${ }^{3}$. Briefly, the transmission efficiency was determined by introducing a with a series of perfluorinated acids, and the fitted mass-dependent transmission efficiency curve was applied to correct the intensity of the detected signals. Finally, the concentrations of NPs, $\mathrm{H}_{2} \mathrm{SO}_{4}$, and levoglucosan were quantified with the calibration factor of NPs or $\mathrm{H}_{2} \mathrm{SO}_{4}$.

The $\mathrm{H}_{2} \mathrm{SO}_{4}$ was calibrated by introducing a certain concentration of gaseous $\mathrm{H}_{2} \mathrm{SO}_{4}$ produced by $\mathrm{SO}_{2}$ reacting with the $\mathrm{OH}$ radicals, which were generated via the photolysis of $\mathrm{H}_{2} \mathrm{O}$ under the irradiation of UV lamp $(185 \mathrm{~nm})^{2,4,5}$. The calibration system has been detailed described in our recent study ${ }^{6}$. Nitrophenols including 2-nitrophenol and 4-nitrophenol were produced from permeation tubes (KIN-TEK) with a permeation rate of $60 \mathrm{ng} / \mathrm{min}$ at $40{ }^{\circ} \mathrm{C}$ and $61 \mathrm{ng} / \mathrm{min}$ at $100{ }^{\circ} \mathrm{C}$, respectively. Nitrophenols were carried by $200 \mathrm{~mL} / \mathrm{min}$ zero air from the permeation tube and then diluted by zero air into various concentrations ranging from several pptv to hundreds of pptv. The diluted nitrophenols were then introduced to the inlet of Tof-CIMS. Based on the calculated concentrations and the signal in Tof-CIMS, the calibration factors of $\mathrm{H}_{2} \mathrm{SO}_{4}$ and nitrophenols could be obtained via equation 1 and 2 . $\left[\mathrm{H}_{2} \mathrm{SO}_{4}\right]$ and [M] were the concentration of generated $\mathrm{H}_{2} \mathrm{SO}_{4}$ and nitrophenol, respectively, $\gamma$ and $\beta$ were the calibration factor for $\mathrm{H}_{2} \mathrm{SO}_{4}$ and nitrophenol, respectively. As shown in Figure S3a, S3b and S3c, almost no response of 2-nitrophenol in Tof-CIMS, and the calibration factor of 4-nitrophenol was determined to be $2.69 \times 10^{10}$ molecule $\mathrm{cm}^{-3}$. The calibration factor of $\mathrm{H}_{2} \mathrm{SO}_{4}$ with the consideration of diffusion loss in the sampling line was $9.88 \times 10^{9}$ molecule $\mathrm{cm}^{-3}$, which was also used to calculate the concentration of levoglucosan.

$$
\begin{gathered}
{\left[\mathrm{H}_{2} \mathrm{SO}_{4}\right]=\gamma \times \ln \left(1+\frac{\left(\mathrm{HSO}_{4}^{-}+\mathrm{H}_{2} \mathrm{SO}_{4} \cdot \mathrm{NO}_{3}^{-}\right)}{\sum_{\mathrm{j}=0}^{2} \mathrm{NO}_{3}^{-} \cdot\left(\mathrm{HNO}_{3}\right)_{\mathrm{j}}}\right)} \\
{[\mathrm{M}]=\beta \times \ln \left(1+\frac{\left(\mathrm{M}^{-}+\mathrm{M} \cdot \mathrm{NO}_{3}^{-}+\mathrm{M} \cdot \mathrm{HNO}_{3} \mathrm{NO}_{3}^{-}\right)}{\sum_{\mathrm{j}=0}^{2} \mathrm{NO}_{3}^{-} \cdot\left(\mathrm{HNO}_{3}\right)_{\mathrm{j}}}\right)}
\end{gathered}
$$

The high-resolution mass spectra allowed precisely achieve the formula of measured organics. However, it could not provide the exact structure information of detected organics. The structure of organics could be inferred from the formula combined with the previous reports. Because the unsaturation degrees of NPs are higher than 4, and 1-2 nitrogen atom with limited oxygen atom presented in their formula, it is unlikely to assign the formula of NPs to organics with chain structure in the real atmosphere. Therefore, the 
structure of the formula of NPs must contain a benzene ring. The location of the functional group could not be determined from the formula. Literature reviews in a similar site could give some possible specific structure for those formulas. $\mathrm{C}_{6} \mathrm{H}_{5} \mathrm{NO}_{3}$ could be 2-nitrophenol, 3-nitrophenol or 4-nitrophenol, or even phenyl nitrates. However, phenyl nitrates usually transform into 2-nitrophenol quickly, which means that the possible structure of $\mathrm{C}_{6} \mathrm{H}_{5} \mathrm{NO}_{3}$ was nitrophenol. Based on the results of previous studies, 2-nitrophenol and 4-nitrophenol should be more ubiquitous than 3-nitrophenol in atmosphere ${ }^{7-9}$. Furthermore, the calibration of 2/4-nitrophenol indicated that the current setup of Tof-CIMS had no response to 2nitrophenol but was sensitive to 4-nitrophenol (Figure S3). Therefore, 4-nitrophenol should dominate the signal of $\mathrm{C}_{6} \mathrm{H}_{5} \mathrm{NO}_{3}$ in our study. The peaks of isotopic ions of $\mathrm{C}_{6} \mathrm{H}_{4} \mathrm{NO}_{3} \mathrm{Cl}$ and $\mathrm{C}_{6} \mathrm{H}_{3} \mathrm{NO}_{3} \mathrm{Cl}_{2}$ were checked to confirm the assignment of Cl-substituted compounds. As shown in Figure S3d, the isotope ions of $\mathrm{C}_{6} \mathrm{H}_{4} \mathrm{NO}_{3}{ }^{37} \mathrm{Cl}$ and $\mathrm{C}_{6} \mathrm{H}_{3} \mathrm{NO}_{3}{ }^{37} \mathrm{Cl}^{37} \mathrm{Cl}$ showed a good correlation with the $\mathrm{C}_{6} \mathrm{H}_{4} \mathrm{NO}_{3}{ }^{35} \mathrm{Cl}_{\text {and }} \mathrm{C}_{6} \mathrm{H}_{3} \mathrm{NO}_{3}{ }^{35} \mathrm{Cl}_{2}$. The RAM slope of the two isotope ions was 0.32 and $0.65\left(\mathrm{R}^{2}=0.994\right.$ and 0.995$)$, which is approximately equal to the expected theoretical value of chlorine isotopic ratio of 0.33 ( $0.65 \mathrm{for}^{\mathrm{Cl}_{2}}$ species), confirming the identification of Cl-NPs. Other compounds with more substitute groups were more complex. However, based on the previous studies on NPs detected by HR-Tof-CIMS ${ }^{1,10-15}$ and by HPLC-MS in Hong Kong ${ }^{8}$, and good correlations between the observed NPs, we assigned the detected formula to the structure of NPs. The identified NPs in this field campaign were summarized in Table S1.

\section{Box model}

The mechanisms in the photochemical box model included inorganic and organic reactions extracted from the Master Chemical Mechanism (MCM v3.3.1; http://mcm.york.ac.uk) ${ }^{16-19}$, the added photolysis mechanisms and deposition of various NPs, a gas-particle partitioning module of NPs, and also the HONO formation/loss mechanisms. The chemical mechanistic information of related organics, including benzene, toluene, xylene, phenol, cresol, isoprene, propene, NPs, etc., and all their reaction intermediates, was extracted from the MCM v3.3.1. Besides, the inorganics reactions were also downloaded from the website and embedded into the model. The parameters and reaction pathways of the extracted mechanisms were used without further modification. 
The reaction pathways of the formation and consumption mechanisms of $\mathrm{C}_{6} \mathrm{H}_{5} \mathrm{NO}_{3}, \mathrm{C}_{7} \mathrm{H}_{7} \mathrm{NO}_{3}$, $\mathrm{C}_{6} \mathrm{H}_{4} \mathrm{~N}_{2} \mathrm{O}_{5}$, and $\mathrm{C}_{7} \mathrm{H}_{6} \mathrm{~N}_{2} \mathrm{O}_{5}$ are summarized and illustrated in Scheme $\mathrm{S} 1$ and Scheme $\mathrm{S} 2$. The reaction of phenoxy $\left(\mathrm{C}_{6} \mathrm{H}_{5} \mathrm{O} \bullet\right)$ and $\mathrm{NO}_{2}$ leads to the generation of 2-nitrophenol, which is the only structure included in MCM 3.3.1. In addition to the oxidation of phenol by $\mathrm{OH}$ and $\mathrm{NO}_{3}$ radicals, the photolysis of $\mathrm{C}_{6} \mathrm{H}_{5} \mathrm{OOH}$, the reaction between phenylperoxy $\left(\mathrm{C}_{6} \mathrm{H}_{5} \mathrm{O}_{2} \bullet\right)$ and $\mathrm{NO} / \mathrm{NO}_{3} \bullet / \mathrm{RO}_{2} \bullet$ also contribute to the generation of $\mathrm{C}_{6} \mathrm{H}_{5} \mathrm{O} \bullet$. After generated in the atmosphere, $\mathrm{C}_{6} \mathrm{H}_{5} \mathrm{NO}_{3}$ could be further oxidized by $\bullet \mathrm{OH}$ and $\mathrm{NO}_{3} \bullet$ to generate nitrophenoxy (NPHEN1O), then to produce $\mathrm{C}_{6} \mathrm{H}_{4} \mathrm{~N}_{2} \mathrm{O}_{5}$ in the presence of $\mathrm{NO}_{2}$. The formation of $\mathrm{C}_{7} \mathrm{H}_{7} \mathrm{NO}_{3}$ is more complex because of more possible structures, including 4-methyl-2-nitrophenol and 6menthyl-2-nitrophenol. The reactions of $\mathrm{NO}_{2}+2$-methyl-phenoxy (TOL1O), $\mathrm{NO}_{2}+3$-methyl-phenoxy (MXYL1O) lead to the formation of 6-methyl-2-nitrophenol, and $\mathrm{NO}_{2}+4$-methyl-phenoxy (PXYL1O) is the direct formation pathway for 4-methyl-2-nitrophenol. TOL1O, MXYL1O, and PXYL1O could be generated from the photolysis of related methylphenyl hydroperoxide (OXYL1OOH, MXYL1OOH, and PXYL1OOH) and the reaction of related methylphenyl proxy radicals (OXYL1OO, MXYL1OO, and PXYL1OO) with $\mathrm{NO} / \mathrm{NO}_{3} \bullet / \mathrm{RO}_{2} \bullet$. Besides, TOL1O could also be generated from the oxidation of cresol by $\bullet \mathrm{OH}$ and $\mathrm{NO}_{3} \bullet$. The generated 6-methyl-2-nitrophenol could be further oxidized by $\bullet \mathrm{OH} / \mathrm{NO}_{3} \bullet$ to generate 2-methyl-4,6-dinitrophenol $\left(\mathrm{C}_{7} \mathrm{H}_{6} \mathrm{~N}_{2} \mathrm{O}_{5}\right)$ via reaction of $\mathrm{NO}_{2}+$ 6-methyl-nitrophenoxy (NCRES1O).

In addition to the oxidation by $\bullet \mathrm{OH}$ and $\mathrm{NO}_{3} \bullet$, the photolysis of NPs identified as an important sink way for them was also input into the model. Bardini et al. and Bejan et al. reported that the photolysis rates of 2-nitrophenol and methyl-2-nitrophenol were $1.4 \%$ and 3.2-7.1\% of the photolysis frequency of $\mathrm{NO}_{2}\left(\mathrm{~J}_{\mathrm{NO} 2}\right)$, respectively, whereas Sangwan et al. reported that the photolysis rate of NPs could up to 2 folds of $\mathrm{J}_{\mathrm{NO} 2}{ }^{20-23}$. The solar absorption of NPs was affected by many factors such as phase, substance, and $\mathrm{pH}$, which may be the reasons for the difference between different studies ${ }^{24}$. Because of the controversial photolysis rate of NPs, a series of settings with $0,0.05 \%, 1.4 \%, 3 \%, 5 \%, 10 \%, 20 \%, 30 \%, 50 \%$ folds of $\mathrm{J}_{\mathrm{NO} 2}$ were used as the photolysis rate of NPs to test the influence of photolysis rate on NPs generation. Dry depositions for NPs at a rate of (0.550 1)/HMIX (HMIX: height of mixing layer) were embedded in the model, in which height of mixing layer varied from $300 \mathrm{~m}$ at night to $1500 \mathrm{~m}$ in the afternoon ${ }^{25}$. 
Gas-particle partitioning of NPs was also considered in the model as Johnson et al. ever used ${ }^{26}$. The concentrations of NPs in particle phase and in gas phase follow equation 3 , in which $F_{i, o m}, M_{o m}, K_{p}, \mathrm{~A}_{i}$ represent the concentration of species $i$ in particle phase, the mass concentration of total organic materials in particle, the partition coefficient of $i$ species and the gaseous concentration of $i$ species, respectively. $K_{p}$ was calculated from equation 4 , where $\mathrm{R}$ is the ideal gas constant, $T$ is temperature, $M W_{o m}$ is the mean molecular weight of organics in particle (assuming it to be $130 \mathrm{~g} / \mathrm{mol}$ ), $\alpha$ is the activity coefficient assumed to be 1 for all NPs, $P_{L}^{o}$ is the saturated vapor pressure. The saturated vapor pressures of 4-nitrophenols were taken from the detected value in the laboratory, and the saturated vapor pressures of remaining NPs were obtained from the theorical calculation tool developed by the University of Manchester (http://umansysprop.seaes.manchester.ac.uk) ${ }^{27,28}$. The saturated vapor pressures were evaluated from their structures via the combination of the approach of Stein and Brown to estimate the boiling temperature and the Nannoolal's method to calculate vapor pressure ${ }^{27-30}$. The change of saturated vapor pressure with temperature was also considered in the model via calculation of the Clausius-Clapeyron relation. The dynamical process of gas-particle partitioning could be treated as an absorption process $\left(k_{\text {in }}\right)$ with a desorption process $\left(k_{o u t}\right)$, and $K_{p}=k_{\text {in }} / k_{\text {out }}$.

$$
\begin{gathered}
F_{i, o m}=K_{p} \times M_{o m} \times A_{i} \\
K_{p}=\frac{7.501 \times 10^{-9} \times R \times T}{M W_{o m} \times \alpha \times P_{L}^{o}}
\end{gathered}
$$

The contribution of the photolysis of NPs to HONO formation was also calculated in the model. However, the reaction mechanisms of the photolysis process for different NPs are still not clear. We assumed a unit yield of HONO in the photolysis of NPs, and the photolysis rates of $1.4 \%$ of $\mathrm{J}_{\mathrm{NO} 2}$ for $\mathrm{C}_{6} \mathrm{H}_{5} \mathrm{NO}_{3}$ and $\mathrm{C}_{6} \mathrm{H}_{4} \mathrm{~N}_{2} \mathrm{O}_{5}$ and $5 \%$ of $\mathrm{J}_{\mathrm{NO} 2}$ for other NPs, based on the simulation results and previous studies $10,22,23$. To evaluate the role of the photolysis of NPs on HONO formation, other reported important sources for HONO were also embedded in the model to calculate the fractions of different sources to HONO formation. Here, the heterogeneous reaction of $\mathrm{NO}_{2}$ on aerosol $\left(\mathrm{Het}-\mathrm{NO}_{2}\right)$, the light-enhancing heterogeneous reaction of $\mathrm{NO}_{2}$ on aerosol $\left(\mathrm{Het}_{h v}-\mathrm{NO}_{2}\right)$, and the photolysis of particle nitrate $\left(\mathrm{PNO}_{3}{ }^{-}\right)$were considered. Additionally, the homogeneous reaction of $\mathrm{OH}+\mathrm{NO}(\mathrm{OH}+\mathrm{NO})$, a default reaction in the model, were also the source of HONO. The uptake coefficients of Het-NO 2 and $\mathrm{Het}_{h v}-\mathrm{NO}_{2}$ used in the study of 
Fu et al. were used in this work ${ }^{31}$. The photolysis rate of $\mathrm{PNO}_{3}{ }^{-}$used here was $\frac{8.3 \times 10^{-5}}{7 \times 10^{-7}} \times \mathrm{J}_{\mathrm{HNO}-\mathrm{MCM}}$, where $\mathrm{J}_{\mathrm{HNO} 3-\mathrm{MCM}}$ is the calculated photolysis rate of gaseous $\mathrm{HNO}_{3}$ in $\mathrm{MCM}$.

A time-dependent model was operated, and a 48-hour spin-up time was applied. The simulation period was from 8 November to 3 December. The observed $\mathrm{NO}, \mathrm{NO}_{2}, \mathrm{SO}_{2}, \mathrm{O}_{3}, \mathrm{CO}, \mathrm{N}_{2} \mathrm{O}_{5}, \mathrm{RH}, \mathrm{T}, \mathrm{J}_{\mathrm{NO} 2}$, benzene, toluene, xylene/ethylbenzene, isoprene, propene, propane, butane, pentane, $i$-butane, $i$-pentane, particle nitrate, organic aerosol, and surface aera of aerosol were input into the model every 10 minutes to constrain the model simulation. The detailed information of their concentrations was summarized in Table S2. In the simulation of di-NPs, the concentrations of mono-NPs were also input to constrain the model. Because only 6-methyl-2-nitrophenol could generate $\mathrm{C}_{7} \mathrm{H}_{6} \mathrm{~N}_{2} \mathrm{O}_{5}$ in the model, the input concentration of $\mathrm{C}_{7} \mathrm{H}_{7} \mathrm{NO}_{3}$ was only used to constrain 6-methyl-2-nitrophenol. Both the observed concentrations of mono-NPs and di-NPs were input to simulate HONO production.

\section{Budget analysis of $\mathrm{C}_{6} \mathrm{H}_{5} \mathrm{NO}_{3}$}

$\mathrm{C}_{6} \mathrm{H}_{5} \mathrm{NO}_{3}$ was directly generated from the reaction between $\mathrm{C}_{6} \mathrm{H}_{5} \mathrm{O} \cdot$ and $\mathrm{NO}_{2} \cdot \mathrm{C}_{6} \mathrm{H}_{5} \mathrm{O} \cdot$ was a photochemical product exhibiting its highest concentration at noontime and several shoulder peaks in the afternoon, while the high concentration of $\mathrm{NO}_{2}$ appeared at around 8:00 am and 8:00 pm (Figure S18c). The concentration changes of $\mathrm{C}_{6} \mathrm{H}_{5} \mathrm{O} \bullet$ and $\mathrm{NO}_{2}$ determined that the production rate of $\mathrm{C}_{6} \mathrm{H}_{5} \mathrm{NO}_{3}$ owned several peaks in the daytime. The formation pathways of $\mathrm{C}_{6} \mathrm{H}_{5} \mathrm{O} \bullet$ include the reaction of $\mathrm{C}_{6} \mathrm{H}_{5} \mathrm{O}_{2} \bullet+\mathrm{NO}$, $\mathrm{C}_{6} \mathrm{H}_{5} \mathrm{O}_{2} \bullet+\mathrm{NO}_{3}, \mathrm{C}_{6} \mathrm{H}_{5} \mathrm{O}_{2} \bullet+\mathrm{RO}_{2} \bullet$, phenol $+\mathrm{NO}_{3} \bullet$, phenol $+\bullet \mathrm{OH}$, and the photolysis of $\mathrm{C}_{6} \mathrm{H}_{5} \mathrm{OOH}$. Among those reactions, the reaction between $\mathrm{C}_{6} \mathrm{H}_{5} \mathrm{O}_{2} \bullet$ and $\mathrm{NO}$ was the most dominant pathway for $\mathrm{C}_{6} \mathrm{H}_{5} \mathrm{O} \bullet$ formation. In turn, $\mathrm{C}_{6} \mathrm{H}_{5} \mathrm{O} \bullet$ could quickly transform into $\mathrm{C}_{6} \mathrm{H}_{5} \mathrm{O}_{2} \bullet$ via $\mathrm{C}_{6} \mathrm{H}_{5} \mathrm{O} \bullet+\mathrm{O}_{3}$, which resulted in that the highest net production rate from $\mathrm{C}_{6} \mathrm{H}_{5} \mathrm{O}_{2} \bullet$ was only $2.53 \mathrm{ppt} / \mathrm{h}$. The oxidation of phenol by $\mathrm{NO}_{3} \bullet$ also contributed significantly to the formation of $\mathrm{C}_{6} \mathrm{H}_{5} \mathrm{O} \bullet$ in the daytime, especially at around 17:00 (up to 4.43 $\mathrm{ppt} / \mathrm{h})$. The reason for it was that phenol owned its high concentration in the daytime, and the concentration of $\mathrm{NO}_{3} \bullet$ started to increase at around 16:00. Therefore, the reaction between phenol and $\mathrm{NO}_{3} \bullet$ played a vital role in the formation of $\mathrm{C}_{6} \mathrm{H}_{5} \mathrm{NO}_{3}$. The contribution of phenol $+\cdot \mathrm{OH}$ and the photolysis of $\mathrm{C}_{6} \mathrm{H}_{5} \mathrm{OOH}$ contributed only a small fraction $(<4 \%)$ to the generation of $\mathrm{C}_{6} \mathrm{H}_{5} \mathrm{NO}_{3}$, owing to the low branching ratio 
to $\mathrm{C}_{6} \mathrm{H}_{5} \mathrm{O} \bullet(0.08$ in phenol $+\cdot \mathrm{OH})$ formation or low concentration.

Photolysis was the dominant sink of $\mathrm{C}_{6} \mathrm{H}_{5} \mathrm{NO}_{3}$ in the daytime, which could even offset the production of $\mathrm{C}_{6} \mathrm{H}_{5} \mathrm{NO}_{3}$ in the noontime to result in a stable or decreased trend of $\mathrm{C}_{6} \mathrm{H}_{5} \mathrm{NO}_{3}$ at that time. With the decrease of solar radiation, the production rate exceeds the consumption rate again in the afternoon. Because of the increased consumption of $\mathrm{C}_{6} \mathrm{H}_{5} \mathrm{NO}_{3}$ by $\mathrm{NO}_{3}$ radical in the evening and the increased deposition rate caused by the decreased mixing layer height, the concentration of $\mathrm{C}_{6} \mathrm{H}_{5} \mathrm{NO}_{3}$ started to sharply decrease at around 17:00 18:00. Hence, the diurnal variation of $\mathrm{C}_{6} \mathrm{H}_{5} \mathrm{NO}_{3}$ was controlled by the concentration change of $\mathrm{NO}_{3} \bullet, \bullet \mathrm{OH}, \mathrm{NO}_{2}, \mathrm{NO}, \mathrm{O}_{3}$, phenol, the precursors of $\mathrm{C}_{6} \mathrm{H}_{5} \mathrm{O}_{2} \bullet$ and the change of photolysis rate. 


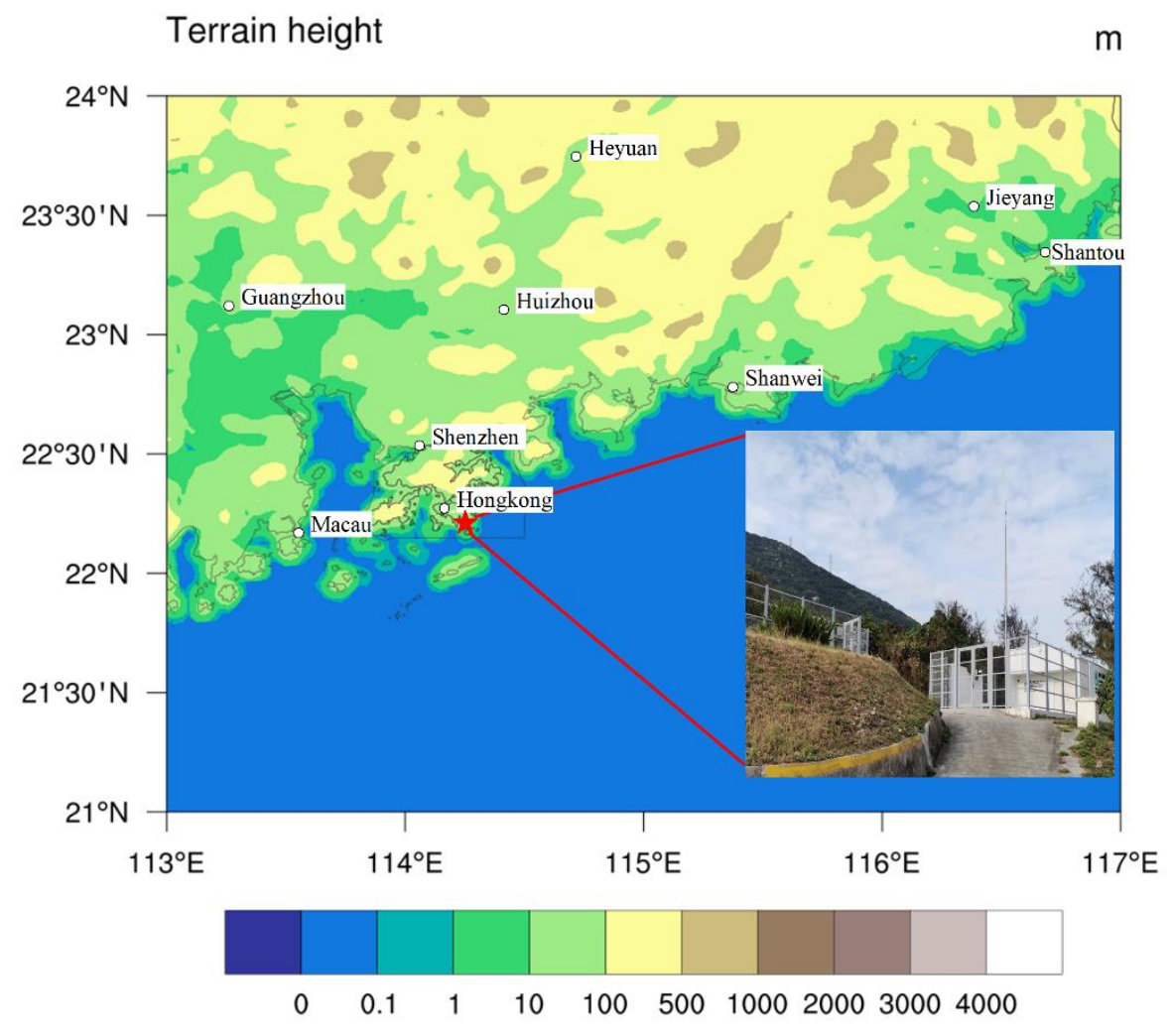

Figure S1. The detail location and surrounding topography of the supersite. 

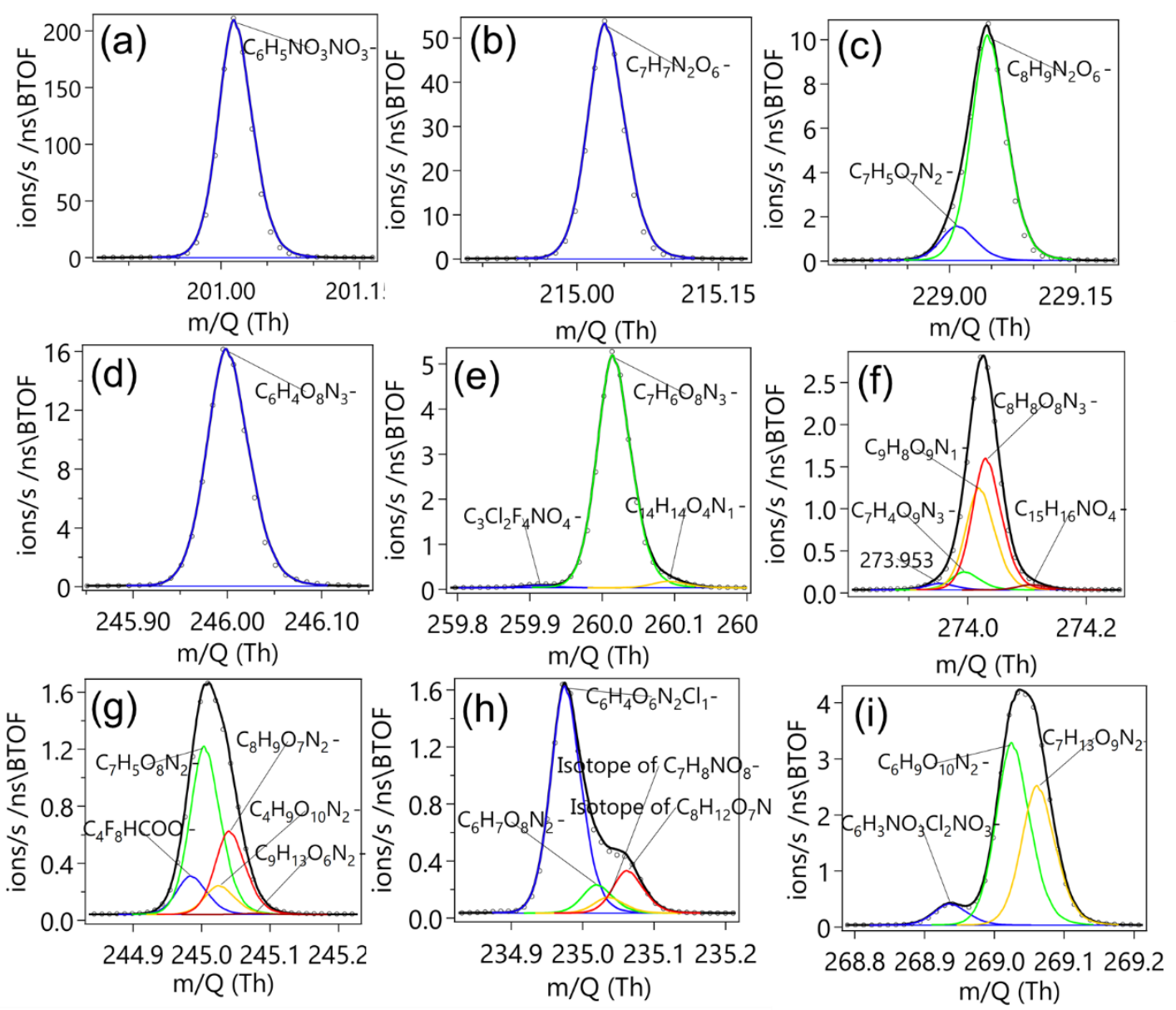

Figure S2. High-resolution peak fitting at m/Q 201, 215, 229, 246, 260, 274, 245, 235 and 269. 

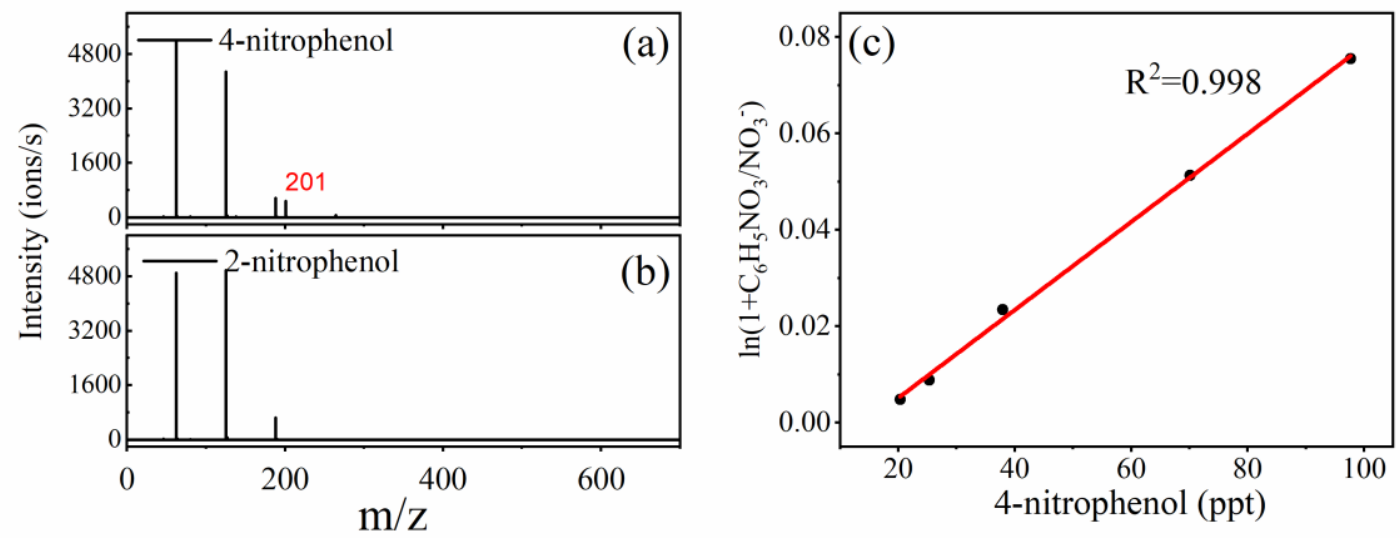

(d)
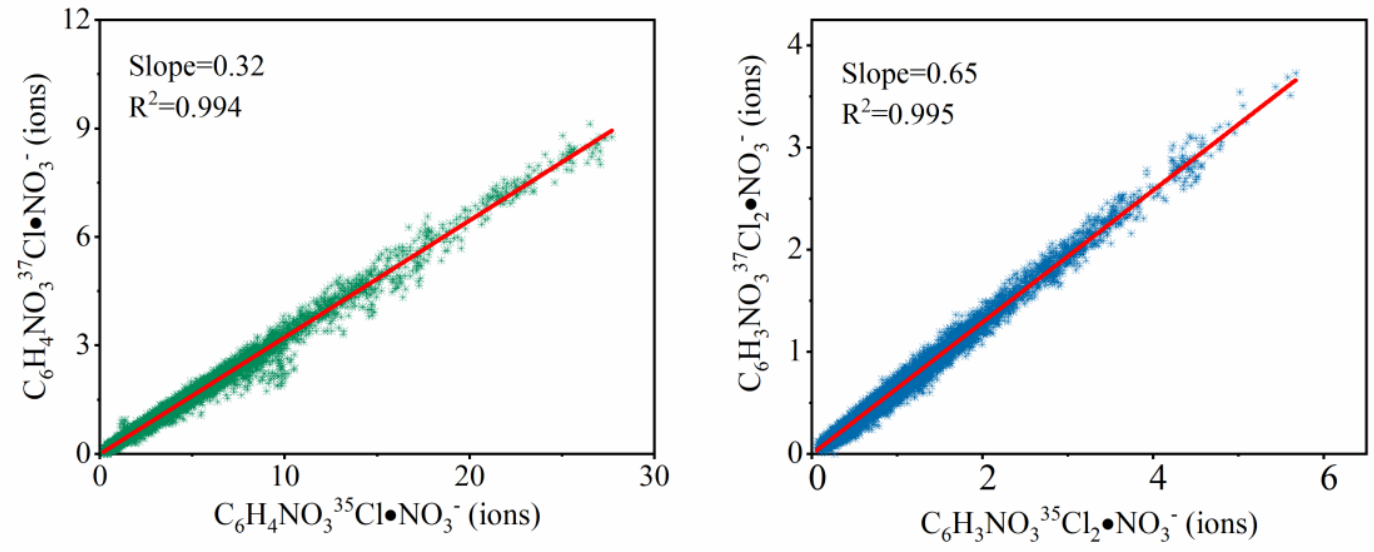

Figure S3. The mass spectra measured by Tof-CIMS when 4-nitrophenol (a) and 2-nitrophenol (b) was introduced; and the calibration result of 4-nitrophenol (c). The correlations between the fitted isotopic signals of $\mathrm{C}_{6} \mathrm{H}_{4} \mathrm{NO}_{3}{ }^{37} \mathrm{Cl} \bullet \mathrm{NO}_{3}{ }^{-}$and $\mathrm{C}_{6} \mathrm{H}_{4} \mathrm{NO}_{3}{ }^{35} \mathrm{Cl} \bullet \mathrm{NO}_{3}{ }^{-}, \mathrm{C}_{6} \mathrm{H}_{3} \mathrm{NO}_{3}{ }^{37} \mathrm{Cl}_{2} \bullet \mathrm{NO}_{3}{ }^{-}$and $\mathrm{C}_{6} \mathrm{H}_{3} \mathrm{NO}_{3}{ }^{35} \mathrm{Cl}_{2} \bullet \mathrm{NO}_{3}{ }^{-}$(d). 


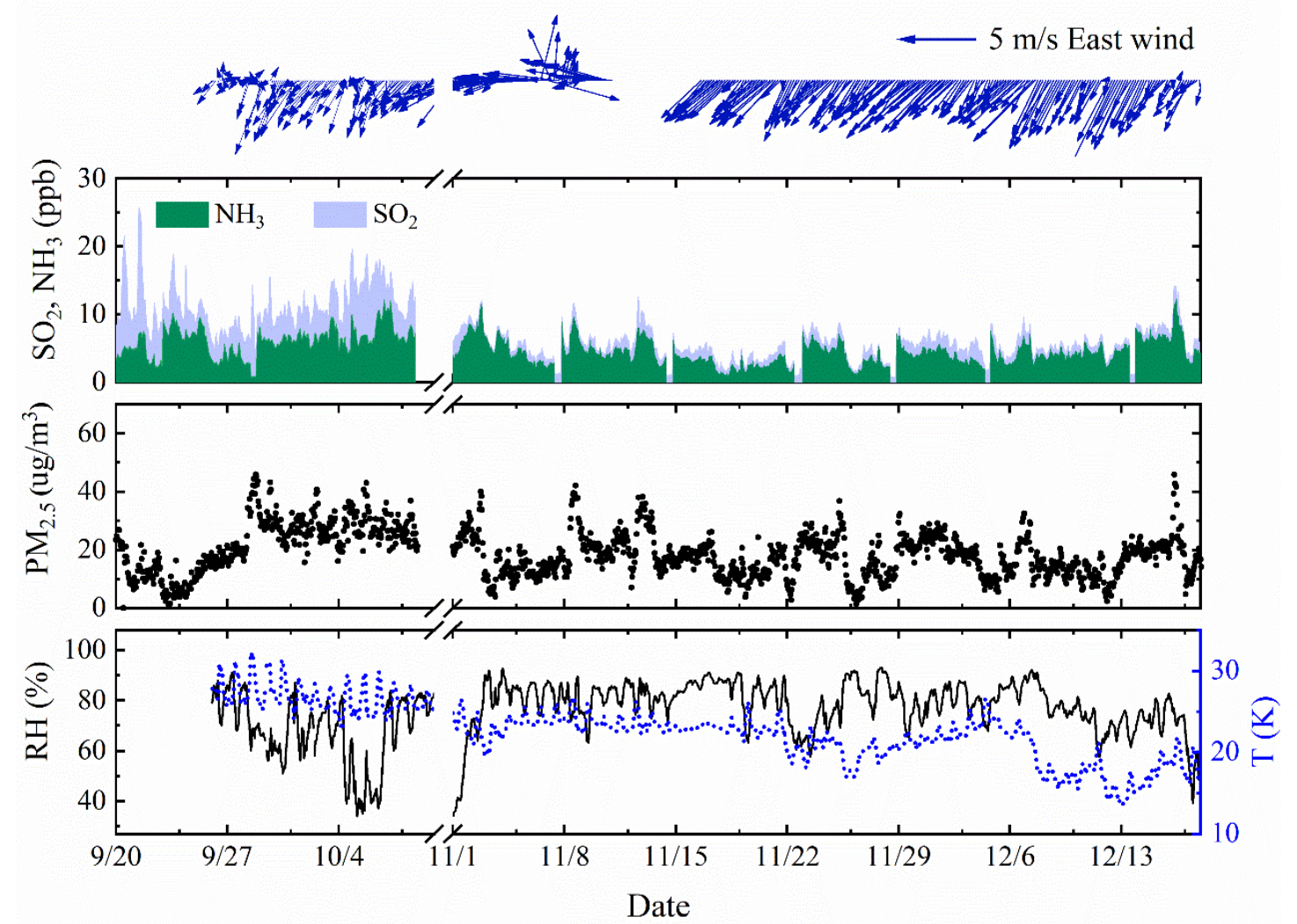

Figure S4. Meteorological parameters (RH, T, wind speed (WS), wind direction (WD)), PM 2.5 , concentration of $\mathrm{SO}_{2}$ and $\mathrm{NH}_{3}$ (stacking area chart) during campaigns. 

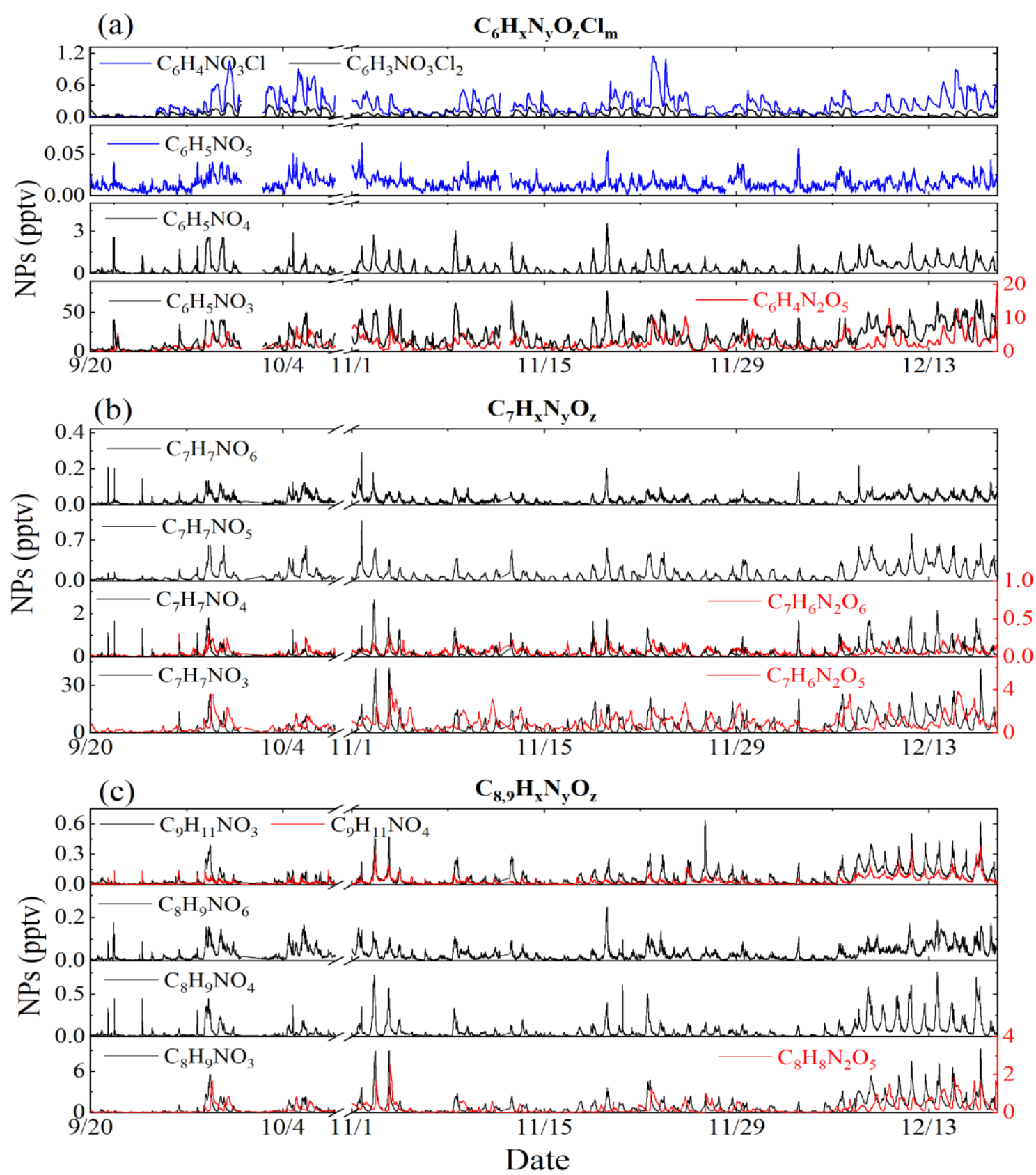

Figure S5. Time series of $\mathrm{C}_{6} \mathrm{H}_{\mathrm{x}} \mathrm{N}_{\mathrm{y}} \mathrm{O}_{\mathrm{z}} \mathrm{Cl}_{\mathrm{m}}$ (a), $\mathrm{C}_{7} \mathrm{H}_{\mathrm{x}} \mathrm{N}_{\mathrm{y}} \mathrm{O}_{\mathrm{z}}$ (b), $\mathrm{C}_{8,9} \mathrm{H}_{\mathrm{x}} \mathrm{N}_{\mathrm{y}} \mathrm{O}_{\mathrm{z}}$ (c) measured at Cape D'aguilar during Sep. 20 to Dec. 18, 2018. 


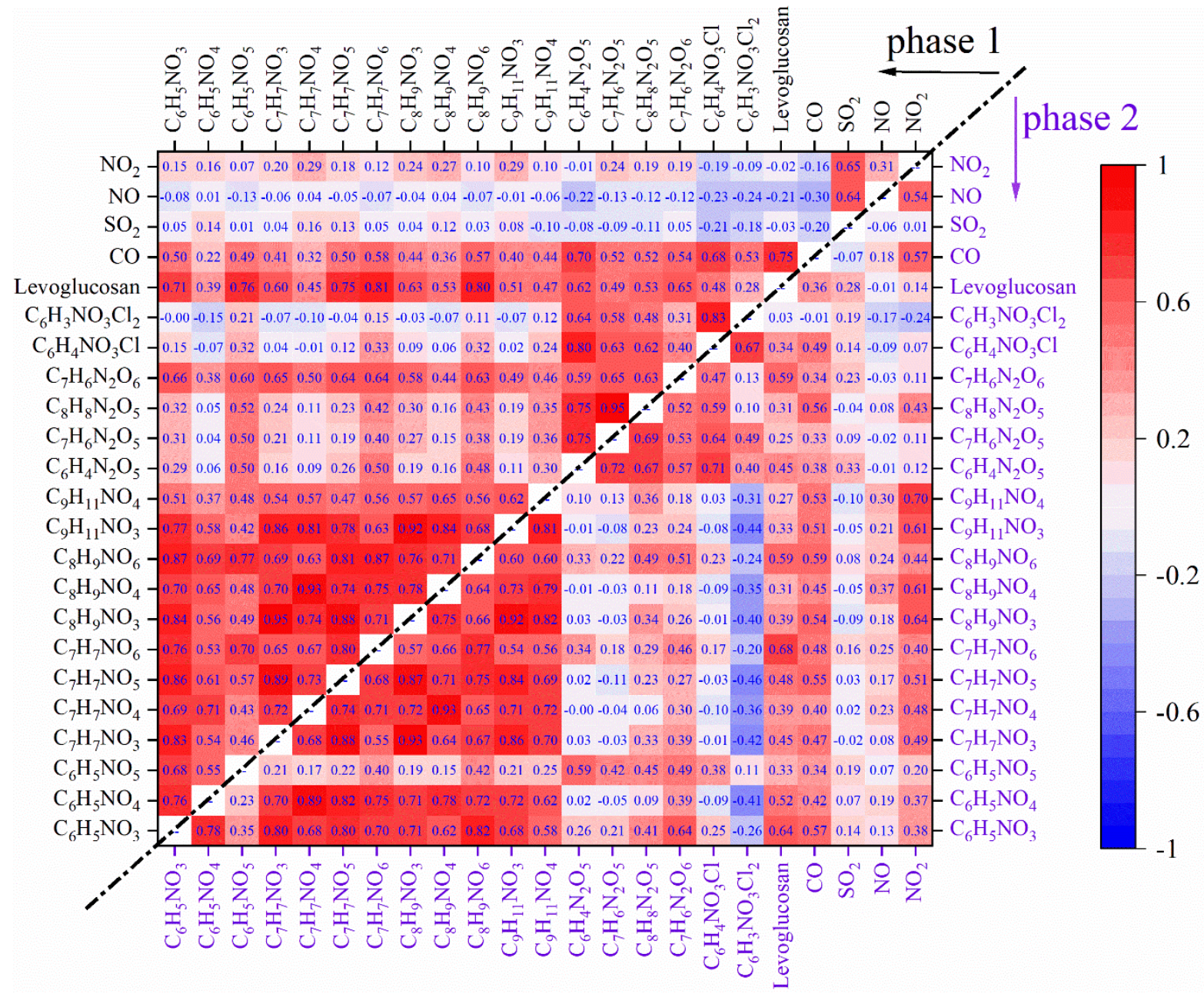

Figure S6. Correlation coefficients among different compounds during phase 1 (the upper left part) and phase 2 (the lower right part). 

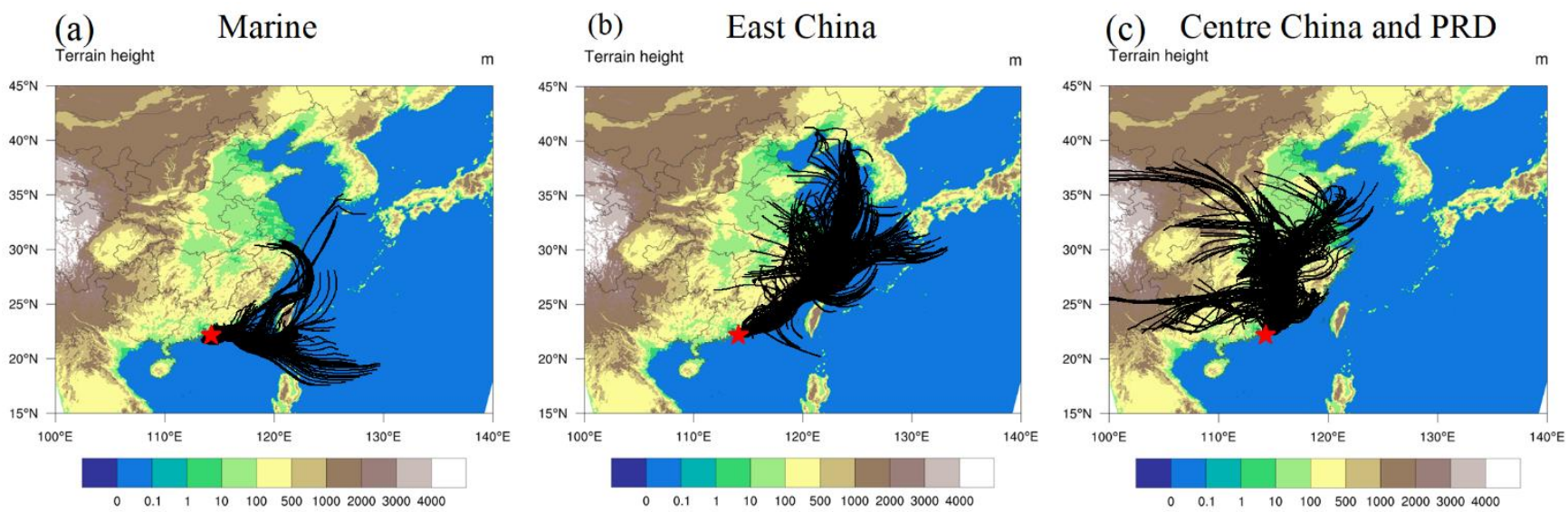

Figure S7. Cluster groups of 72-h backward trajectory of air masses arriving at the observation site simulated using the HYSPLIT model. The cluster 1 (a), cluster 2 (b) and cluster 3 (c) represent the air flow from marine, East China, Centre China and PRD region, respectively. 
(a) Mono-NPs
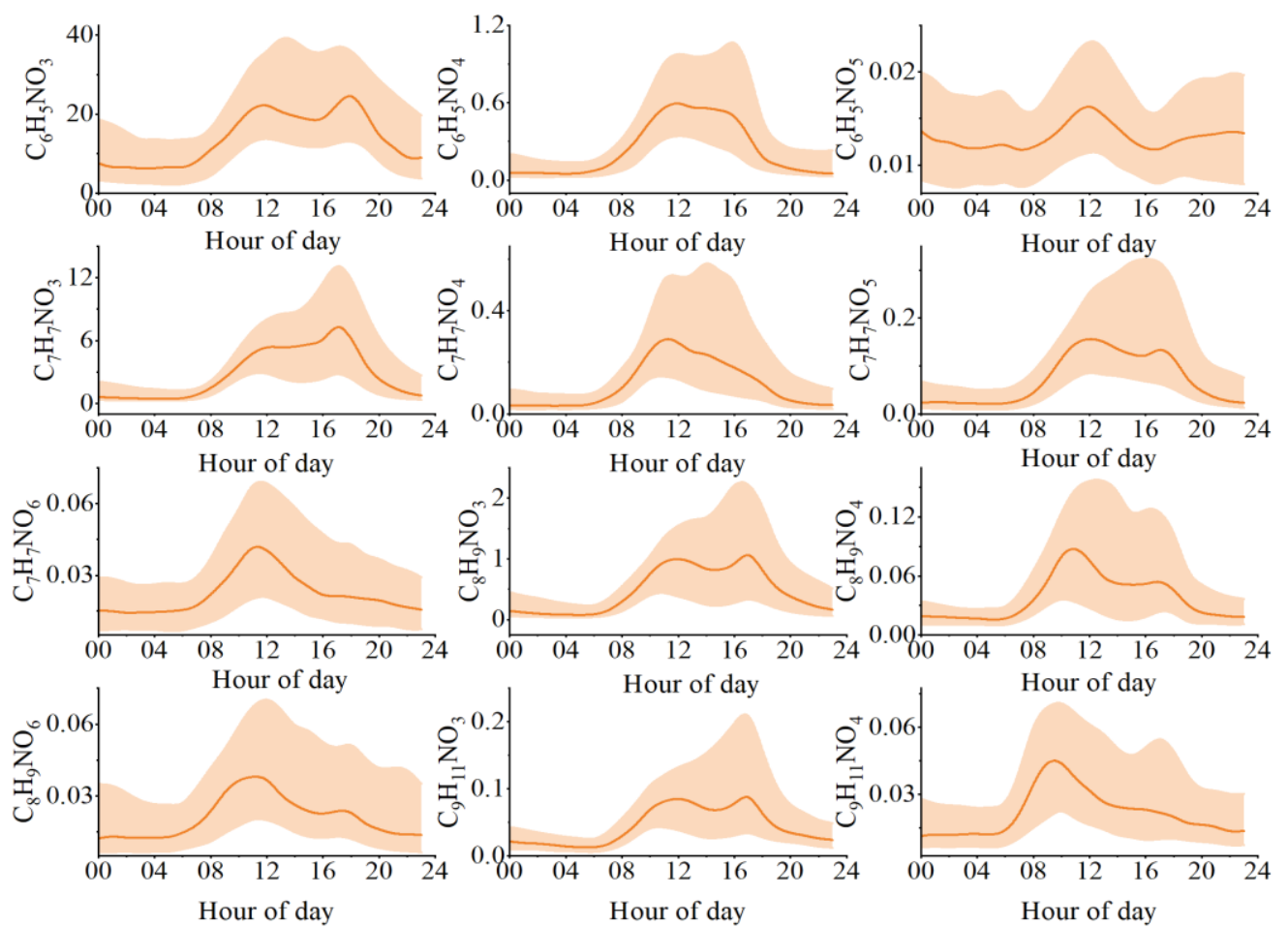

(b) Di-NPs
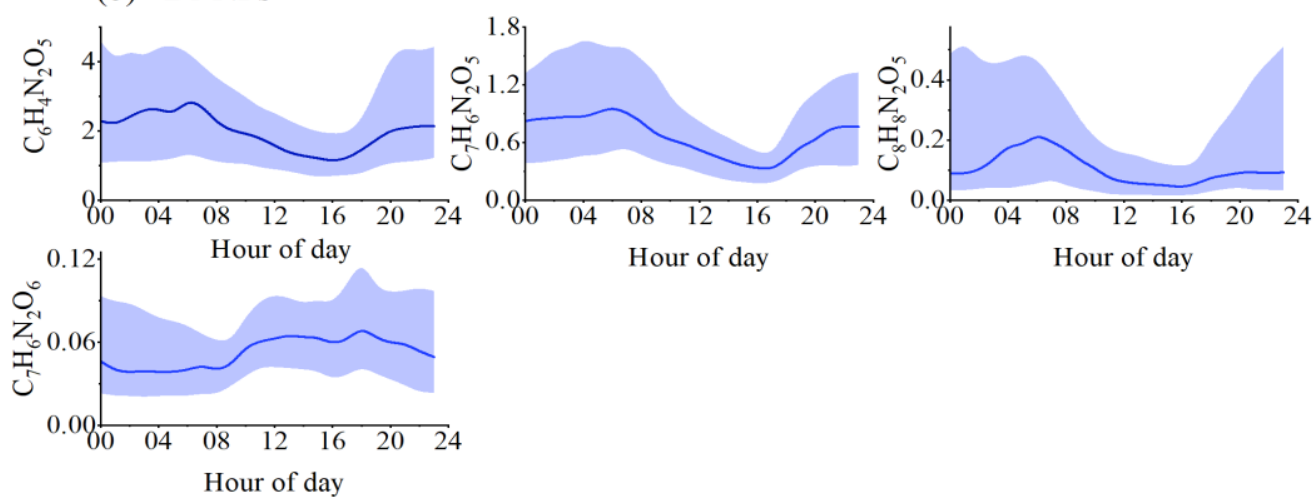

(c) Cl-NPs

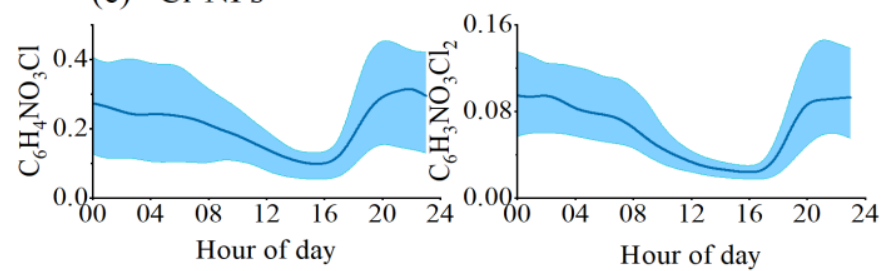

Figure S8. Diurnal pattern of individual mono-NP (a), di-NP (b), and Cl-NP (c). The line, the top and bottom of the shadow area represent the median value, $25 \%$ and $75 \%$ quantiles, respectively. 


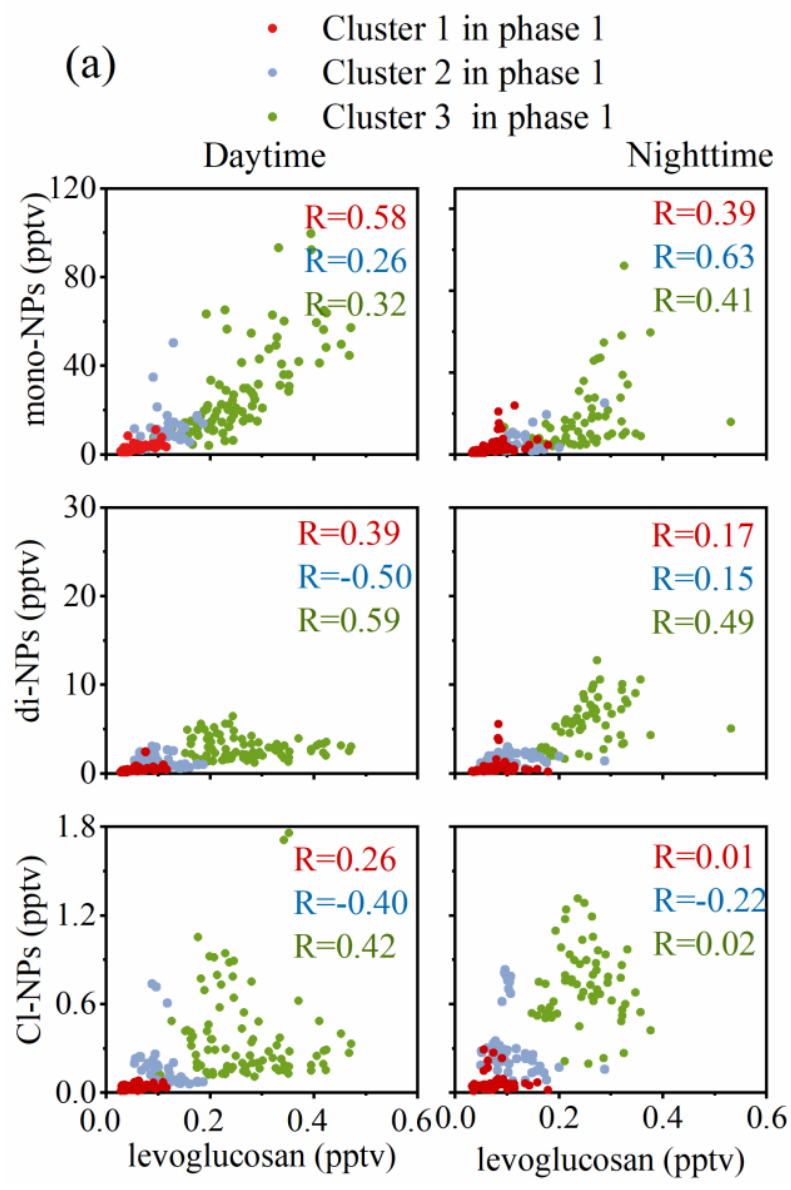

$\begin{array}{ll}\text { (b) } \quad & \text { Cluster } 1 \text { in phase } 2 \\ & \circ \text { Cluster } 2 \text { in phase } 2 \\ \circ & \text { Cluster } 3 \text { in phase } 2\end{array}$
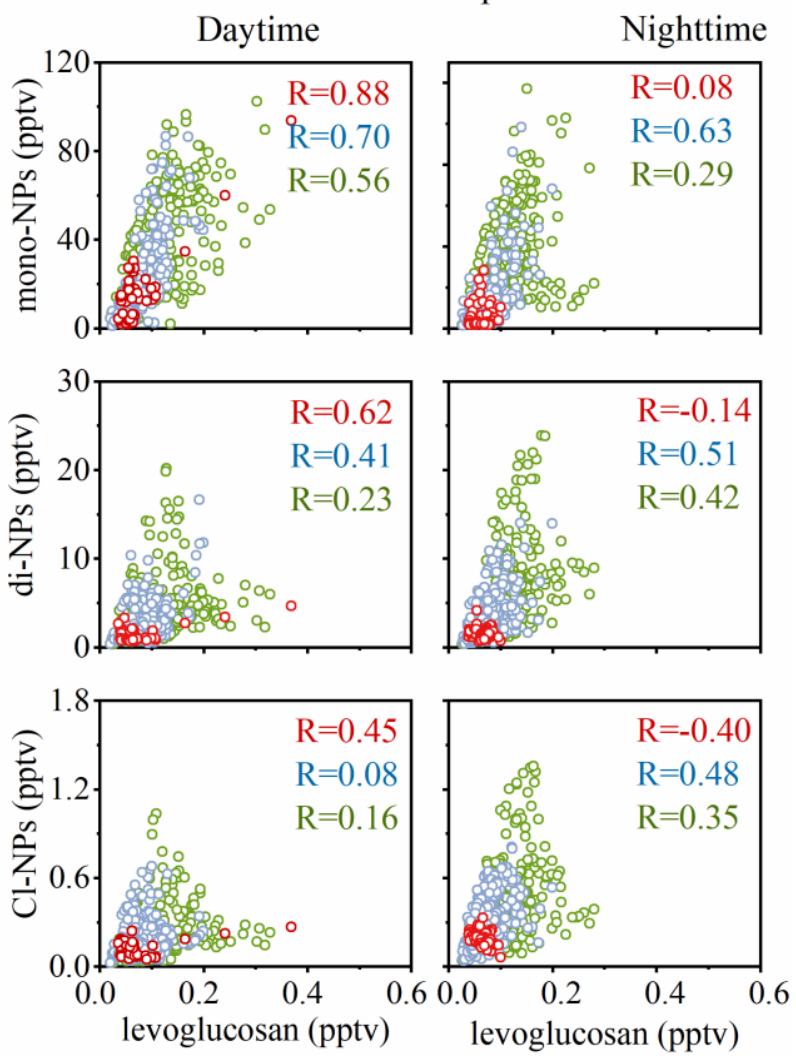

Figure S9. Correlations between levoglucosan and detected NPs in different clusters during the two phases measurements. 
- Cluster 1 in phase 1

(a)
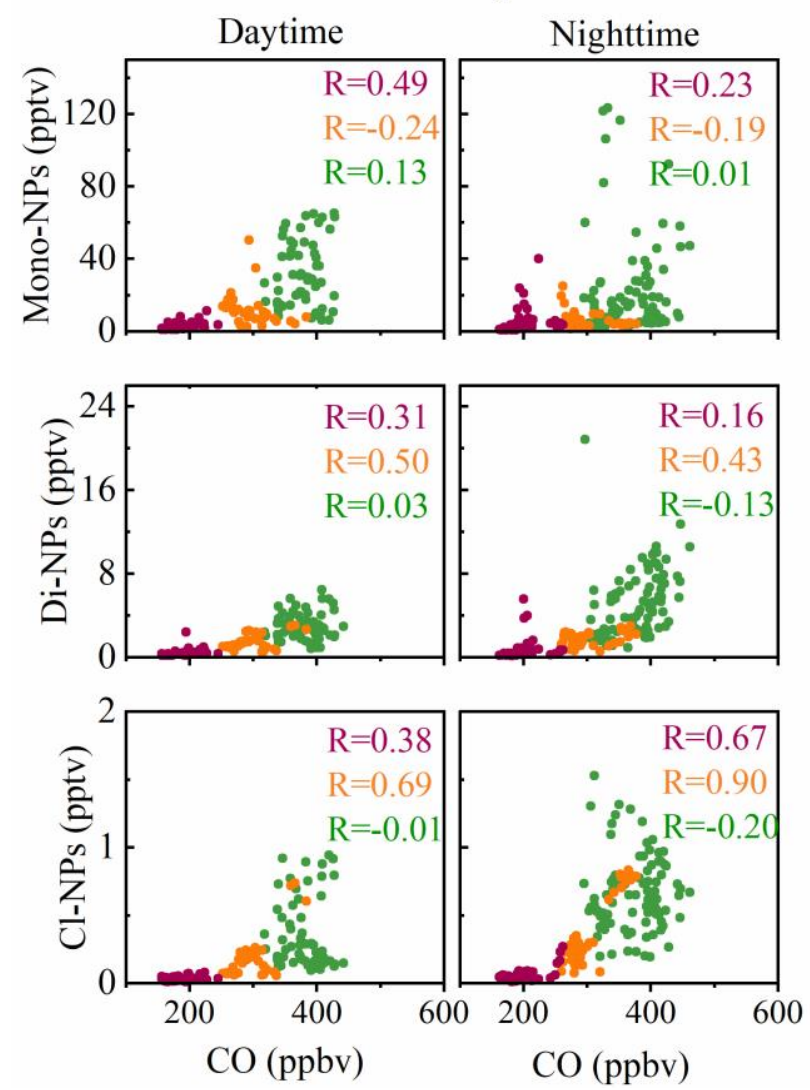

$\circ$ Cluster 1 in phase 2

(b) $\quad$ Cluster 2 in phase 2

- Cluster 3 in phase 2
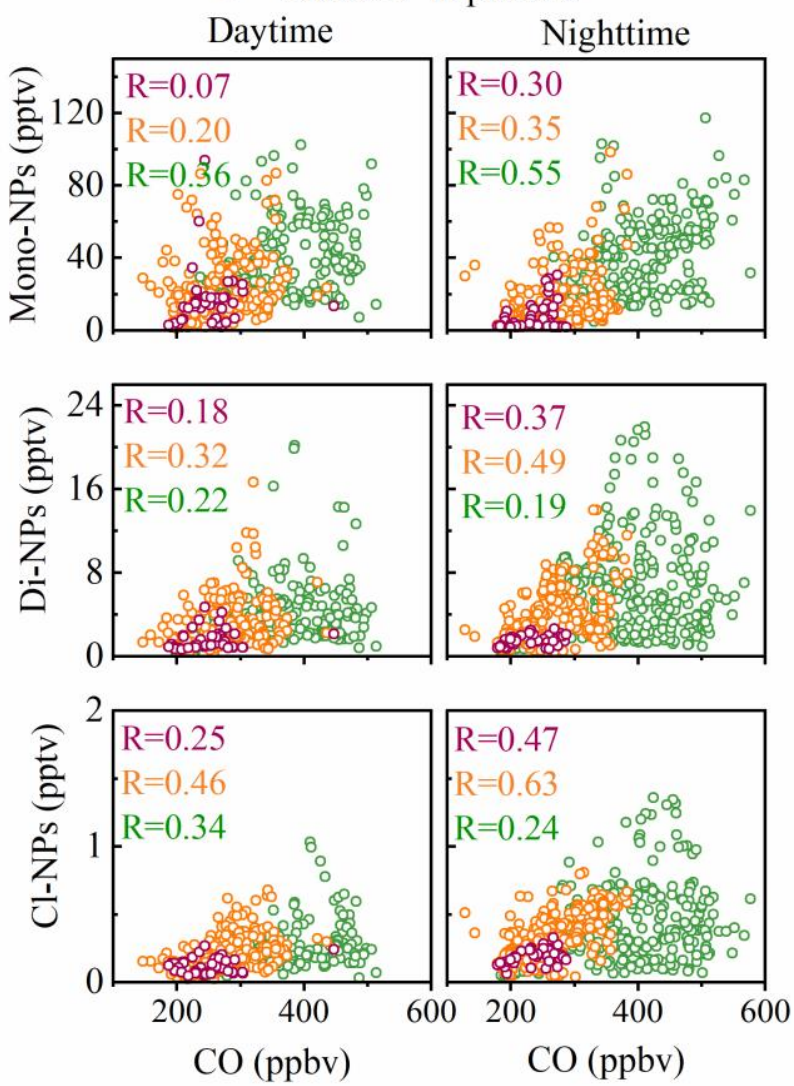

Figure S10. Correlations between CO and detected NPs in different clusters during the two phases measurements. 

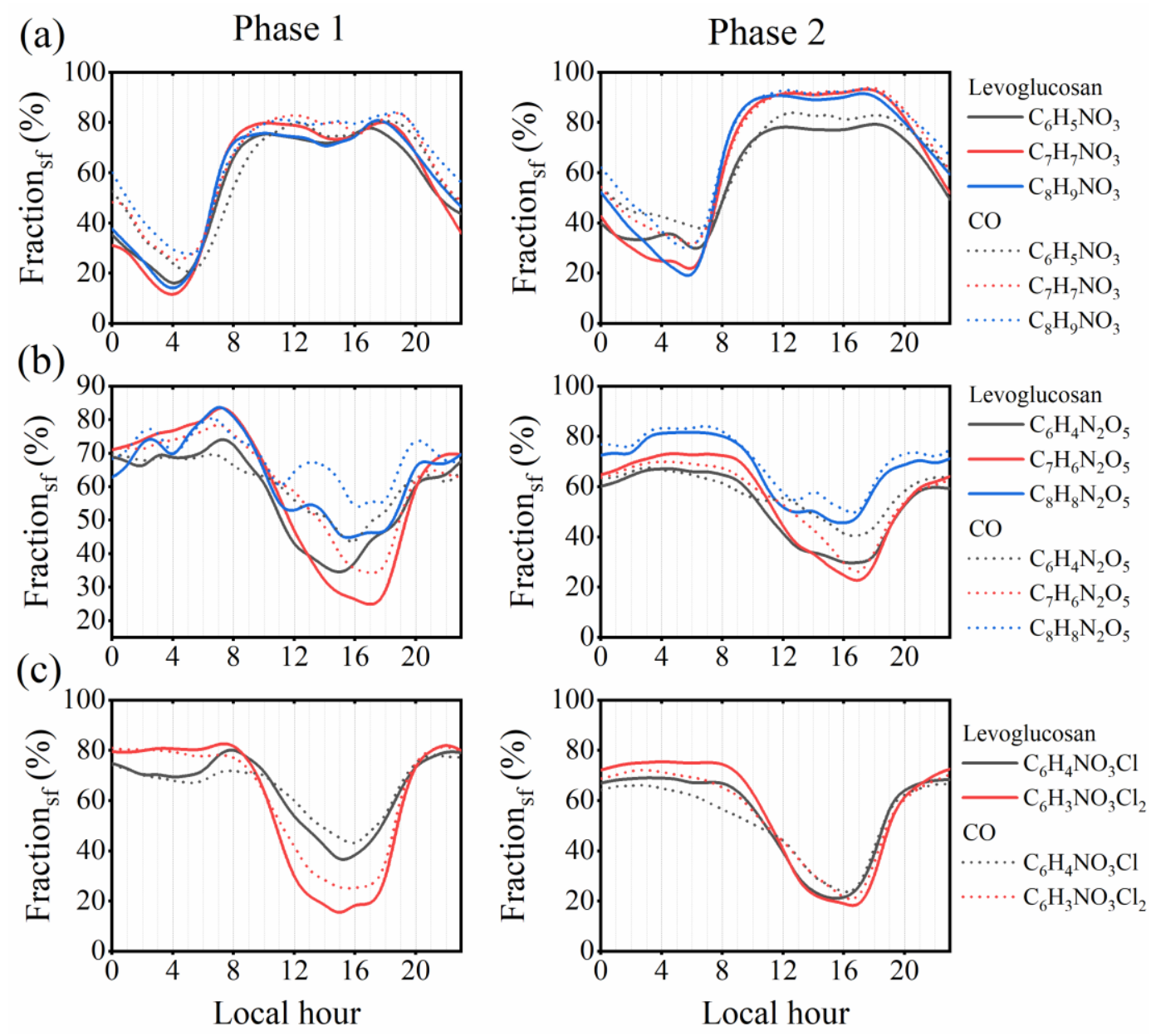

Figure S11. The fraction of secondary formation $\left(\right.$ Fraction $_{\mathrm{sf}}$ ) of mono-NPs (a), di-NPs (b) and Cl-NPs (c) calculated with levoglucosan and CO tracer method in phase 1 and phase 2. 

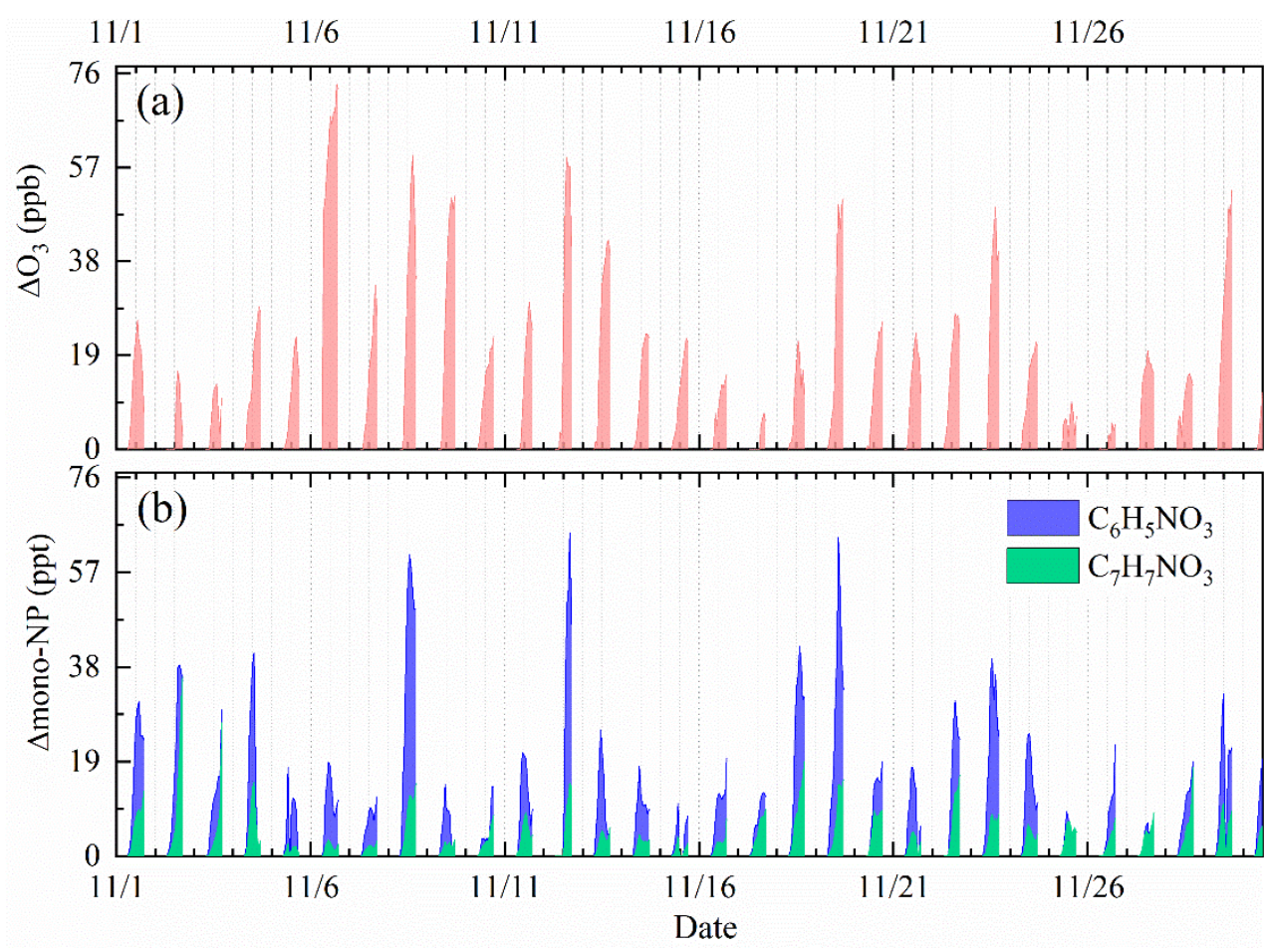

Figure S12. Time series of $\Delta \mathrm{O}_{3}$ (change of $\mathrm{O}_{3}$ concentration at daytime to its concentration at 6:00 am) and $\Delta$ mono-NP (change of mono-NP concentration at daytime to its concentration at 6:00 am) at daytime. 


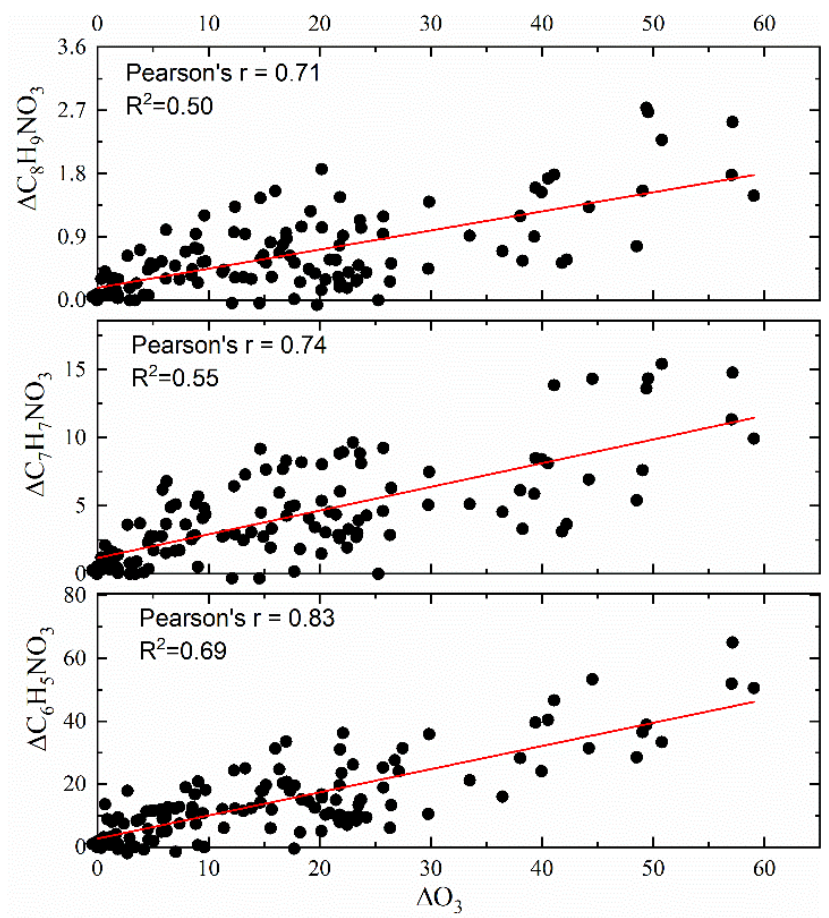

Figure S13. Correlations between $\Delta \mathrm{O}_{3}$ and $\triangle$ mono-NP (same definition in Figure S12) at daytime during 11-26 November 2018. 

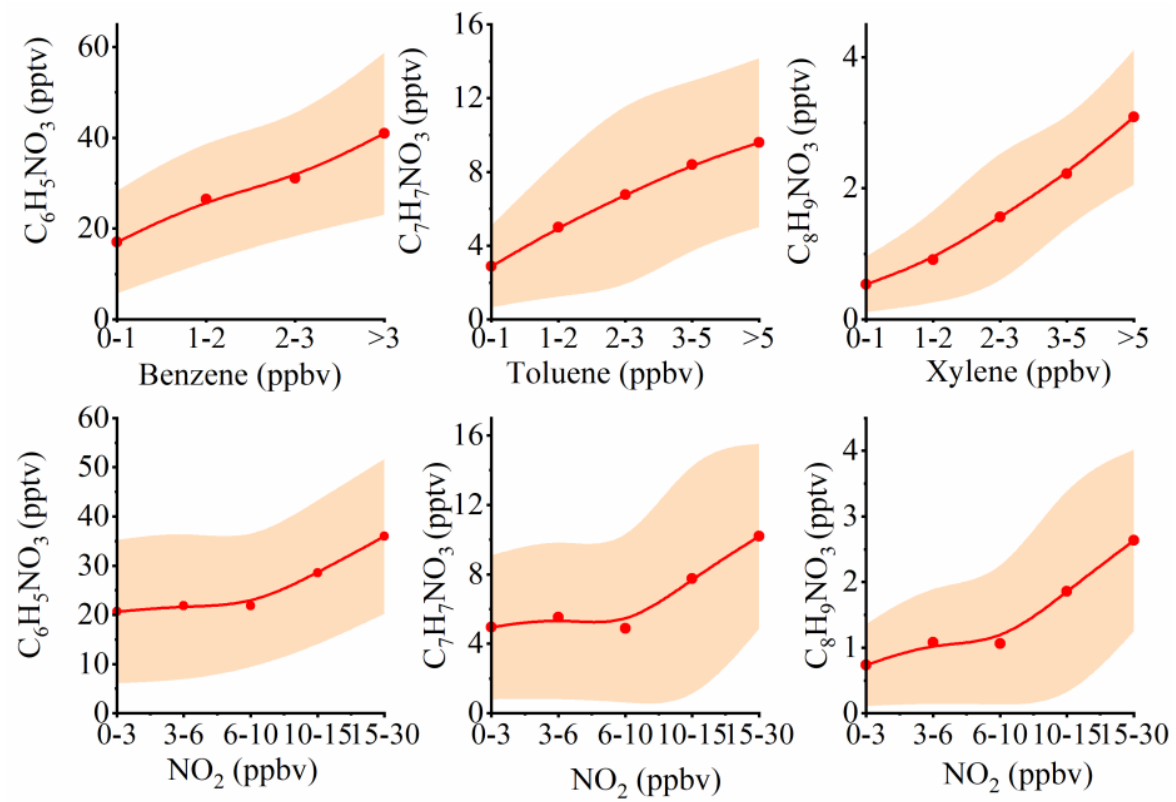

Figure S14. The relationship of $\mathrm{C}_{6} \mathrm{H}_{5} \mathrm{NO}_{3}, \mathrm{C}_{7} \mathrm{H}_{7} \mathrm{NO}_{3}, \mathrm{C}_{8} \mathrm{H}_{9} \mathrm{NO}_{3}$ with related aromatics and $\mathrm{NO}_{2}$ concentration bins in the daytime. 

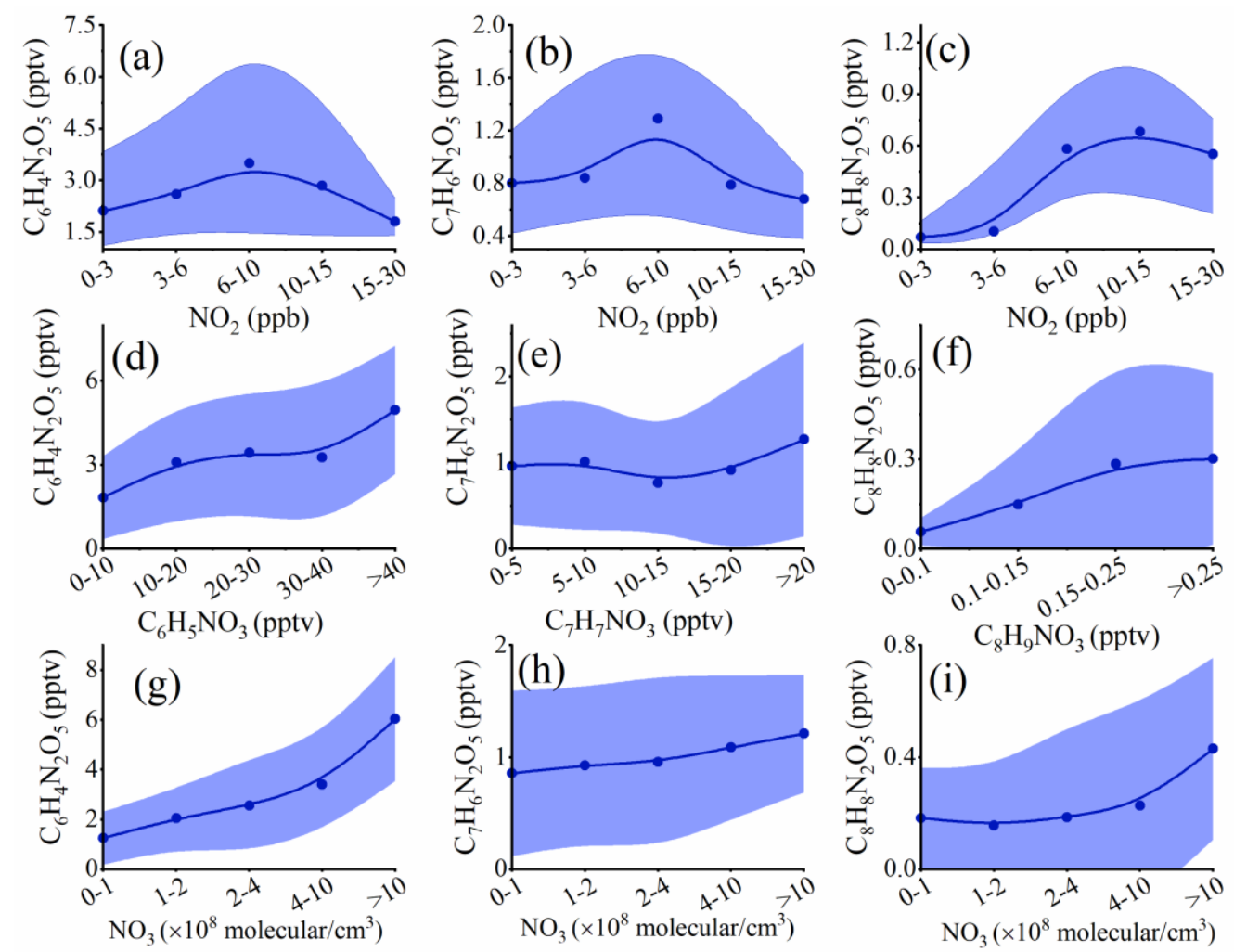

Figure S15. The relationship of $\mathrm{C}_{6} \mathrm{H}_{4} \mathrm{~N}_{2} \mathrm{O}_{5}, \mathrm{C}_{7} \mathrm{H}_{6} \mathrm{~N}_{2} \mathrm{O}_{5}$ and $\mathrm{C}_{8} \mathrm{H}_{8} \mathrm{~N}_{2} \mathrm{O}_{5}$ with their related mono-NPs, $\mathrm{NO}_{2}$ and $\mathrm{NO}_{3} \bullet$ at nighttime. 

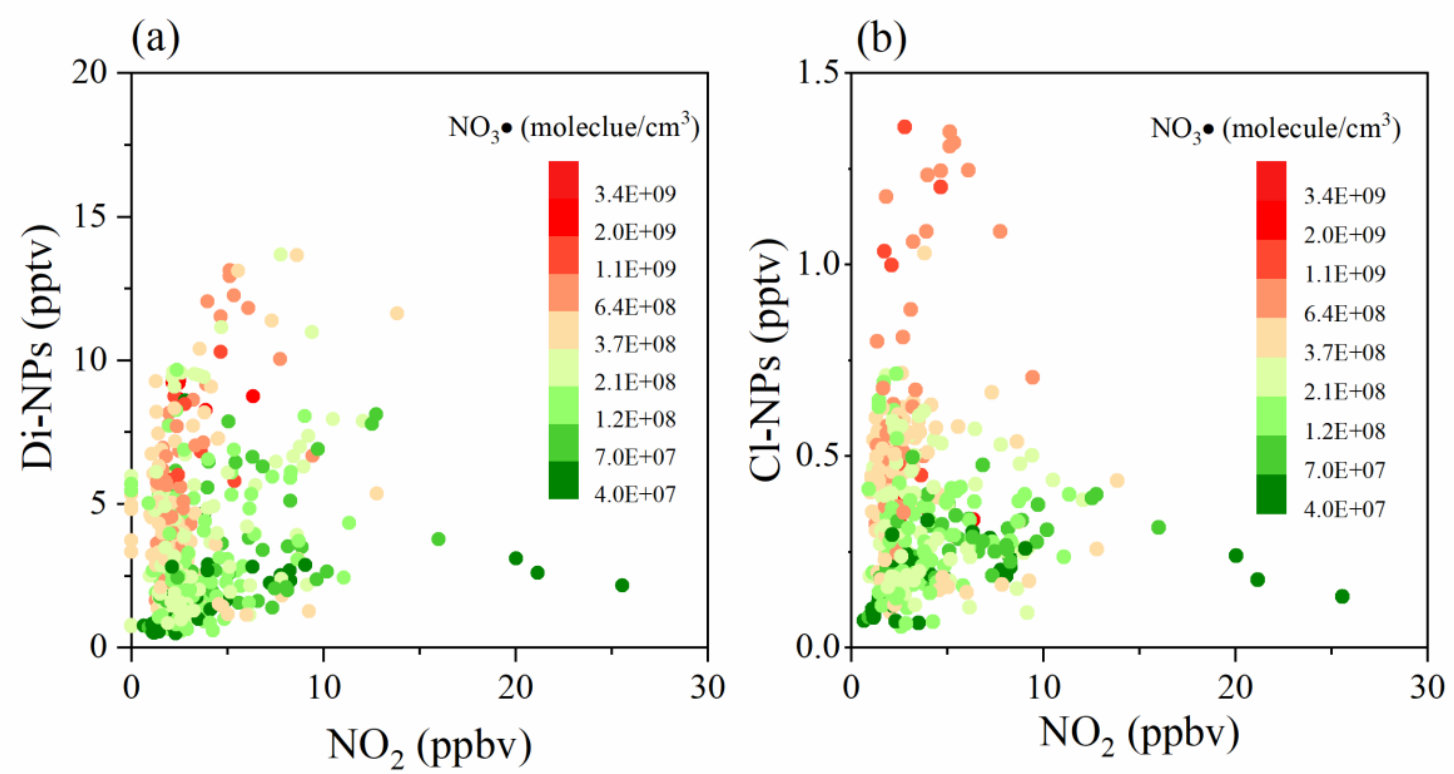

Figure S16. The concentration distribution of di-NPs (a) and Cl-NPs (b) as a function of the concentration of $\mathrm{NO}_{2}$ and colored with $\mathrm{NO}_{3} \bullet$ concentration.
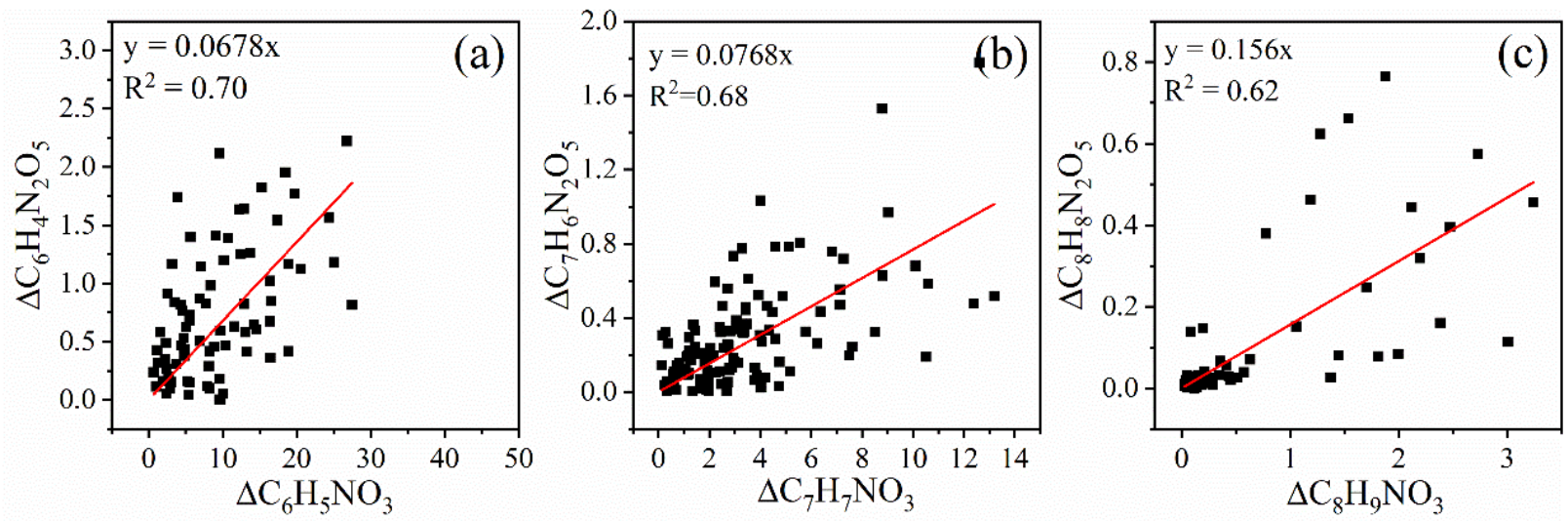

Figure S17. The fitted result of transformation coefficient for $\mathrm{C}_{6} \mathrm{H}_{4} \mathrm{~N}_{2} \mathrm{O}_{5}, \mathrm{C}_{7} \mathrm{H}_{6} \mathrm{~N}_{2} \mathrm{O}_{5}$ and $\mathrm{C}_{8} \mathrm{H}_{8} \mathrm{~N}_{2} \mathrm{O}_{5}$ during 19:00 to $24: 00$. 


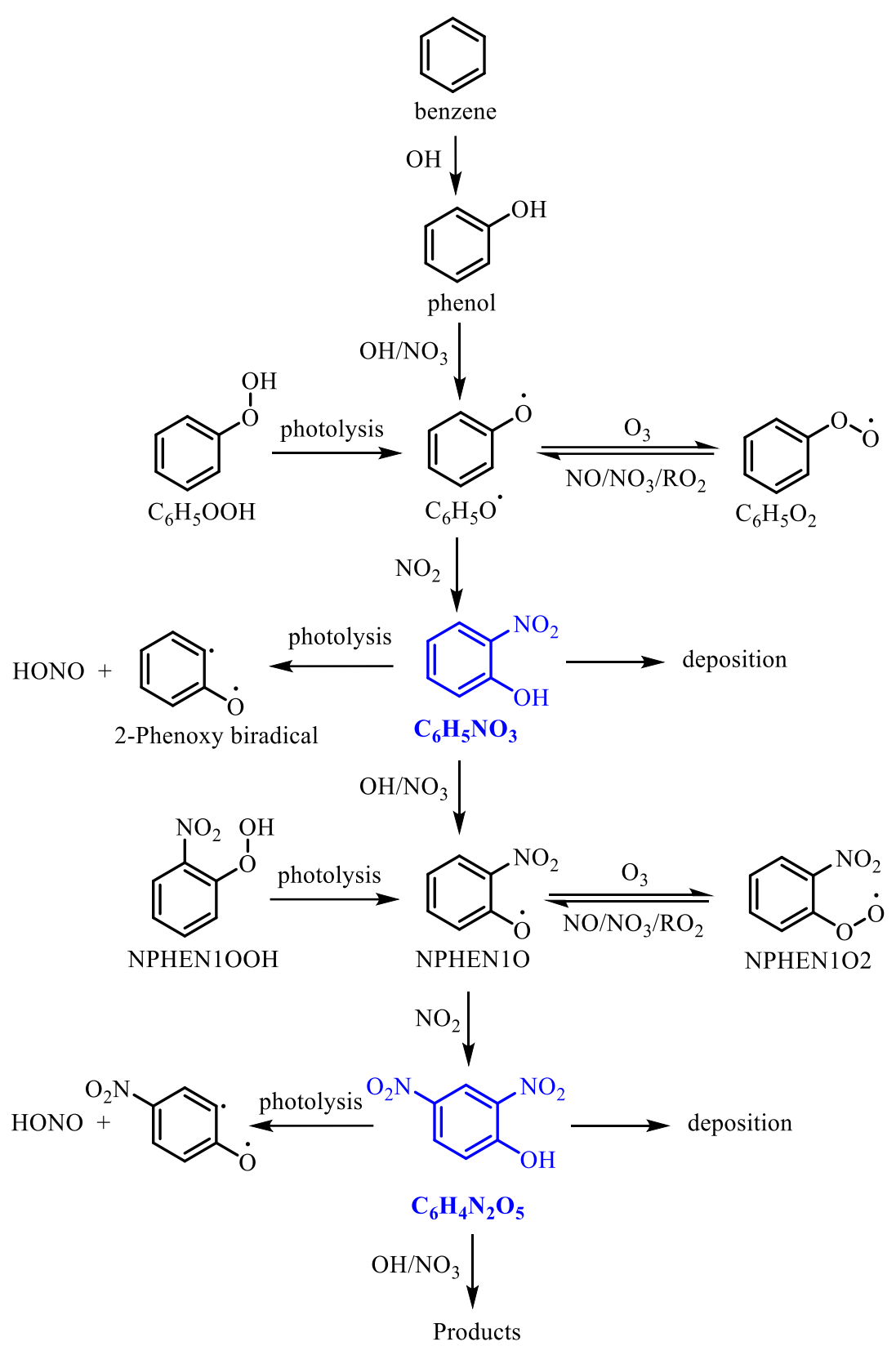

Scheme S1. The formation and consumption mechanisms for $\mathrm{C}_{6} \mathrm{H}_{5} \mathrm{NO}_{3}$ and $\mathrm{C}_{6} \mathrm{H}_{4} \mathrm{~N}_{2} \mathrm{O}_{5}$. 


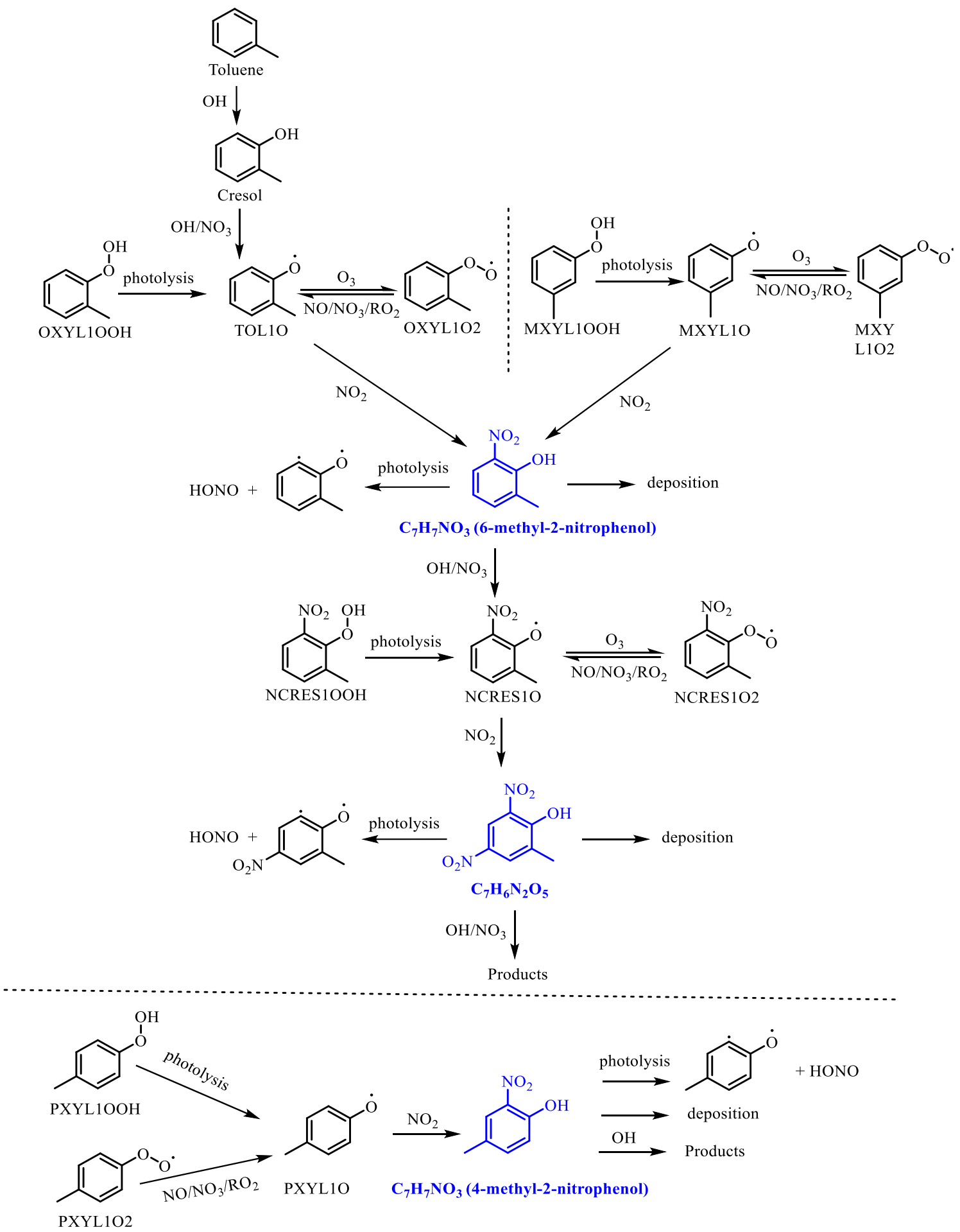

Scheme S2. The formation and consumption mechanisms for $\mathrm{C}_{7} \mathrm{H}_{7} \mathrm{NO}_{3}$ (including 6-methyl-2nitrophenol and 4-methyl-2-nitrophenol) and $\mathrm{C}_{7} \mathrm{H}_{6} \mathrm{~N}_{2} \mathrm{O}_{5}$. 
(a)
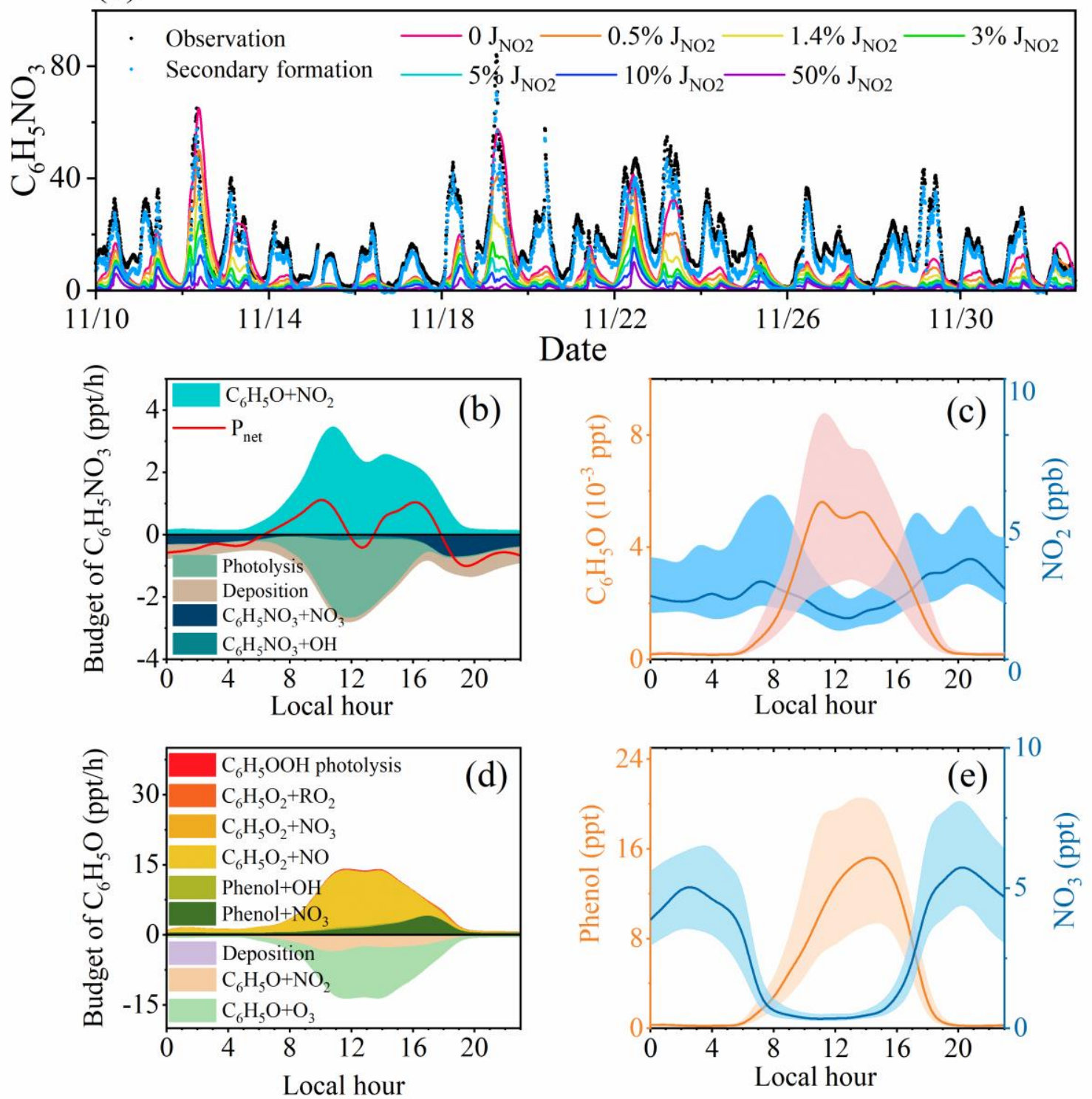

Figure S18. The comparison of model simulated $\mathrm{C}_{6} \mathrm{H}_{5} \mathrm{NO}_{3}$ to the observed $\mathrm{C}_{6} \mathrm{H}_{5} \mathrm{NO}_{3}$ and secondary fractions calculated $\mathrm{C}_{6} \mathrm{H}_{5} \mathrm{NO}_{3}$ (a), budget of $\mathrm{C}_{6} \mathrm{H}_{5} \mathrm{NO}_{3}$ (b), diurnal variation of $\mathrm{C}_{6} \mathrm{H}_{5} \mathrm{O}$ and $\mathrm{NO}_{2}$ (c), budget of $\mathrm{C}_{6} \mathrm{H}_{5} \mathrm{O}$ (d) and diurnal variation of phenol and $\mathrm{NO}_{3}$ radical (e). 

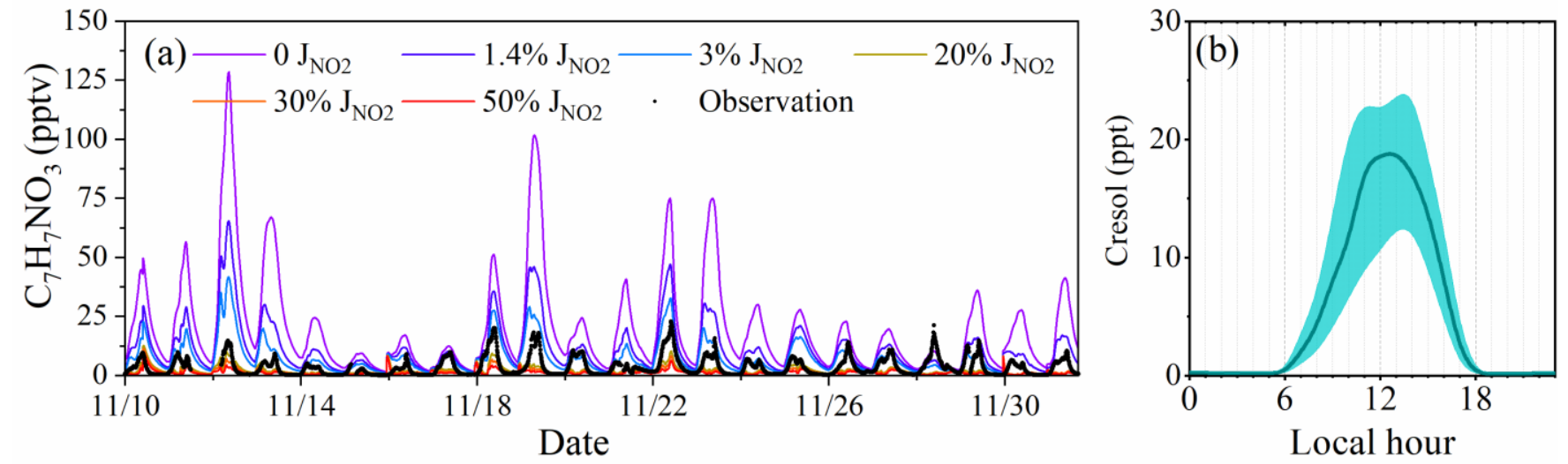

Figure S19. The time series of observed and simulated $\mathrm{C}_{7} \mathrm{H}_{7} \mathrm{NO}_{3}$ (a), and diurnal variation of cresol (b).
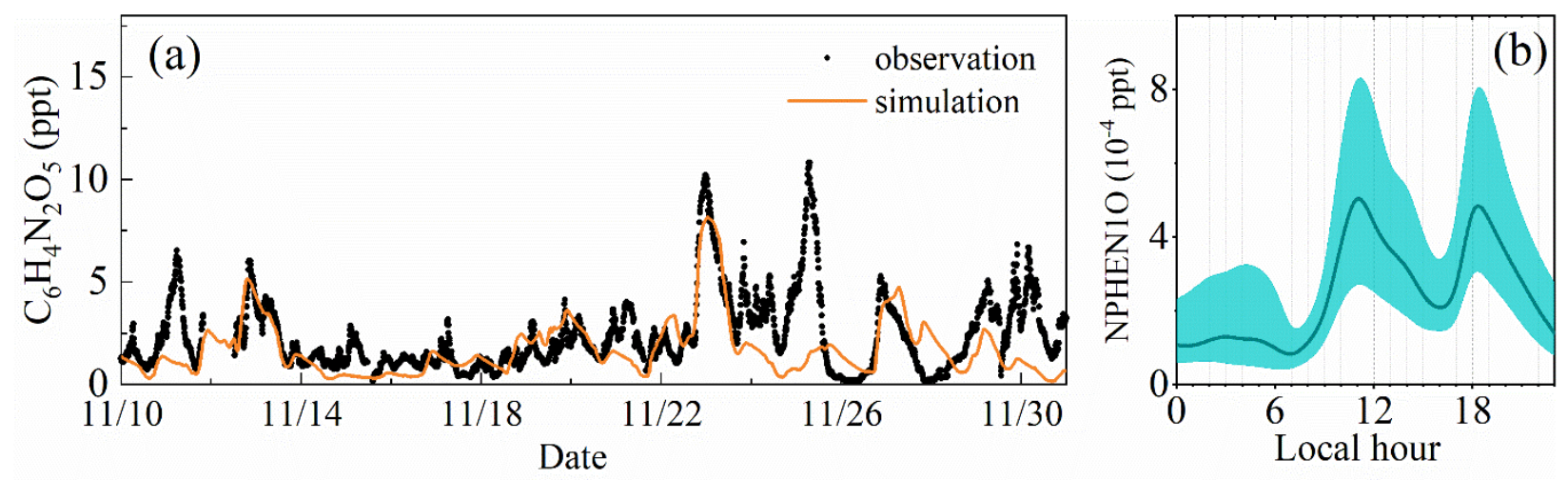

Figure S20. The time series of observed and simulated $\mathrm{C}_{6} \mathrm{H}_{4} \mathrm{~N}_{2} \mathrm{O}_{5}(\mathrm{a})$, and diurnal variation of NPHEN1O (b). 

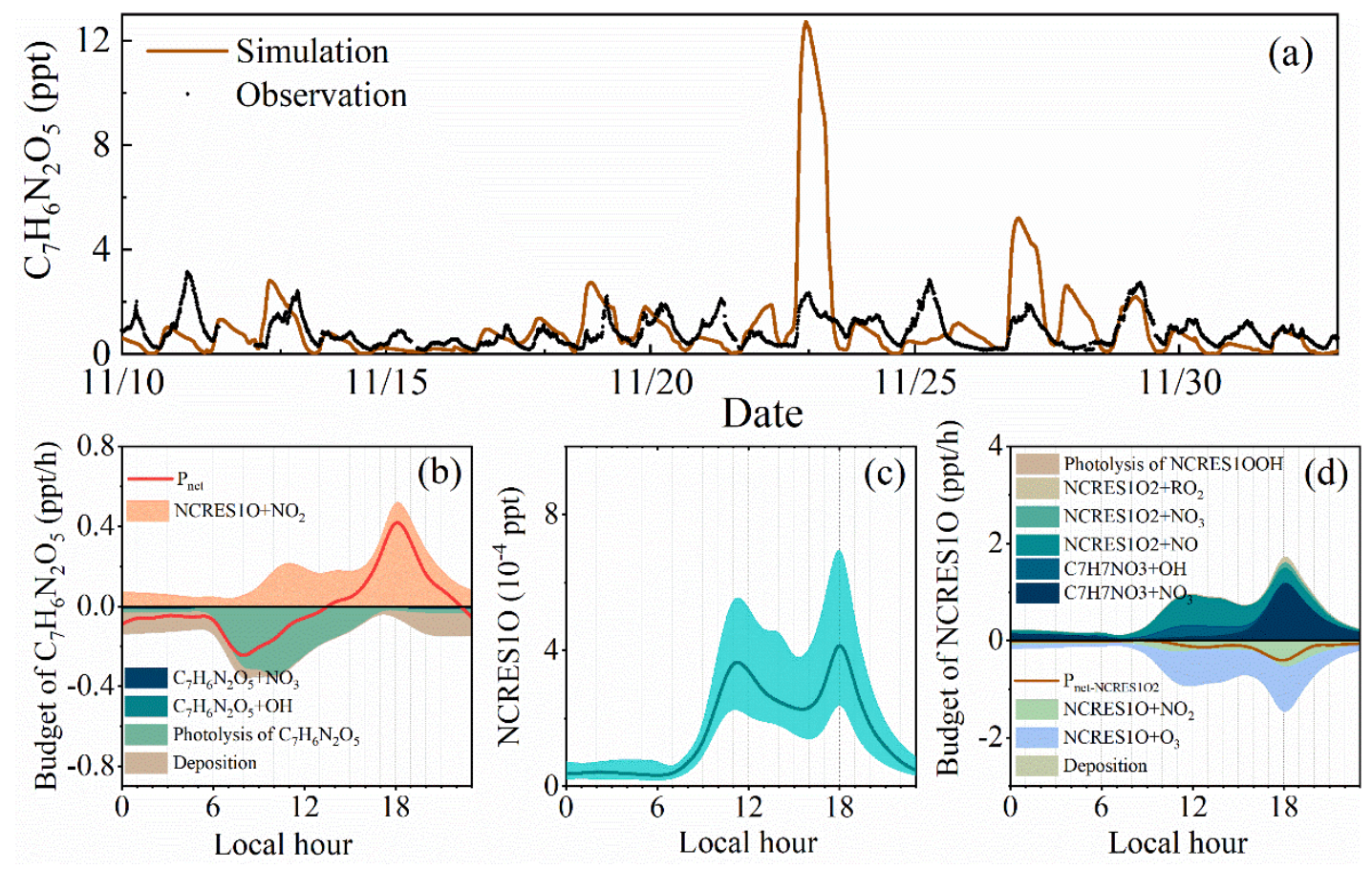

Figure 21. The time series of observed and simulated $\mathrm{C}_{7} \mathrm{H}_{6} \mathrm{~N}_{2} \mathrm{O}_{5}$ (a), and the simulated budget of $\mathrm{C}_{7} \mathrm{H}_{6} \mathrm{~N}_{2} \mathrm{O}_{5}$ (b), diurnal variation of NCRES1O (c), and budget of NCRES1O (d). 

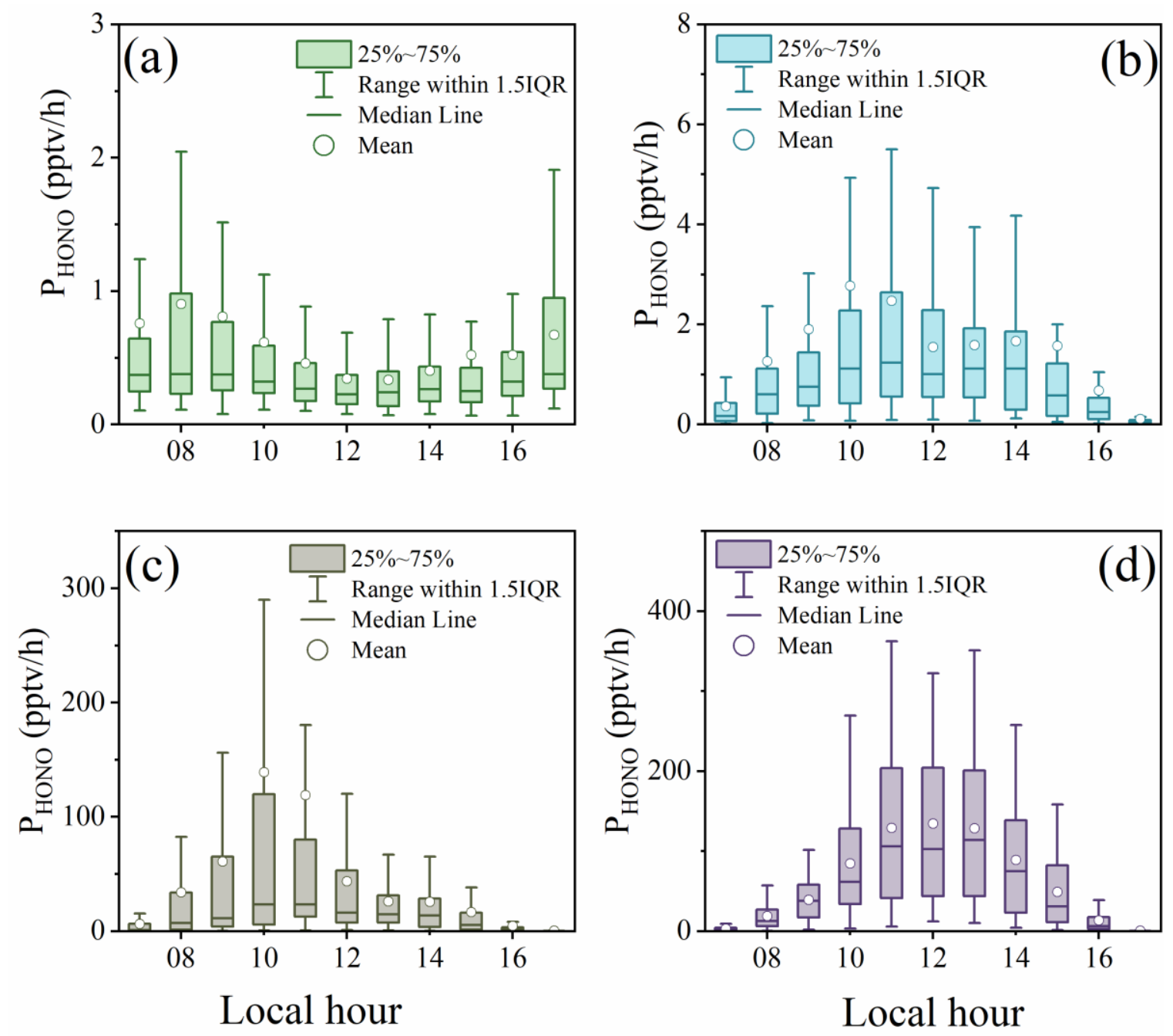

Figure S22. The production rate of $\mathrm{HONO}$ from the heterogeneous reaction of $\mathrm{NO}_{2}$ on aerosol (a), the light-enhanced heterogeneous reaction of $\mathrm{NO}_{2}$ on aerosol (b), the homogeneous reaction $\mathrm{OH}+\mathrm{NO}$ (c), the photolysis of particle nitrate (d). IQR was inter quartile range. 
Table S1. The summary of NPs concentrations measured at Cape D'aguilar during Sep. 20-Dec.18, 2018

\begin{tabular}{|c|c|c|c|c|c|}
\hline Compound & Maximum $^{\text {a }}$ & Average $^{a}$ & Cluster $1^{\text {a }}$ & Cluster $2^{\text {a }}$ & Cluster $^{a}$ \\
\hline \multicolumn{6}{|l|}{ Mono-NPs } \\
\hline $\mathrm{C}_{6} \mathrm{H}_{5} \mathrm{NO}_{3}$ & 84.0 & $16.9 \pm 14.6$ & $5.8 \pm 8.6$ & $13.2 \pm 11.8$ & $23.98 \pm 14.7$ \\
\hline $\mathrm{C}_{7} \mathrm{H}_{7} \mathrm{NO}_{3}$ & 41.7 & $4.0 \pm 5.2$ & $1.1 \pm 2.2$ & $2.7 \pm 3.8$ & $6.0 \pm 6.1$ \\
\hline $\mathrm{C}_{8} \mathrm{H}_{9} \mathrm{NO}_{3}$ & 9.3 & $0.9 \pm 1.1$ & $0.2 \pm 0.3$ & $0.4 \pm 0.5$ & $1.3 \pm 1.4$ \\
\hline $\mathrm{C}_{9} \mathrm{H}_{11} \mathrm{NO}_{3}$ & 0.65 & $0.07 \pm 0.08$ & $0.02 \pm 0.03$ & $0.04 \pm 0.04$ & $0.11 \pm 0.23$ \\
\hline $\mathrm{C}_{6} \mathrm{H}_{5} \mathrm{NO}_{4}$ & 5.5 & $0.4 \pm 0.6$ & $0.2 \pm 0.7$ & $0.2 \pm 0.3$ & $0.6 \pm 0.6$ \\
\hline $\mathrm{C}_{7} \mathrm{H}_{7} \mathrm{NO}_{4}$ & 2.92 & $0.2 \pm 0.31$ & $0.07 \pm 0.16$ & $0.11 \pm 0.17$ & $0.3 \pm 0.37$ \\
\hline $\mathrm{C}_{8} \mathrm{H}_{9} \mathrm{NO}_{4}$ & 0.79 & $0.06 \pm 0.1$ & $0.02 \pm 0.04$ & $0.03 \pm 0.04$ & $0.11 \pm 0.23$ \\
\hline $\mathrm{C}_{9} \mathrm{H}_{11} \mathrm{NO}_{4}$ & 0.39 & $0.03 \pm 0.04$ & $0.01 \pm 0.01$ & $0.02 \pm 0.02$ & $0.06 \pm 0.16$ \\
\hline $\mathrm{C}_{6} \mathrm{H}_{5} \mathrm{NO}_{5}$ & 0.23 & $0.01 \pm 0.01$ & $0.01 \pm 0.01$ & $0.01 \pm 0.02$ & $0.02 \pm 0.13$ \\
\hline $\mathrm{C}_{7} \mathrm{H}_{7} \mathrm{NO}_{5}$ & 1.12 & $0.11 \pm 0.13$ & $0.03 \pm 0.03$ & $0.06 \pm 0.07$ & $0.18 \pm 0.23$ \\
\hline $\mathrm{C}_{7} \mathrm{H}_{7} \mathrm{NO}_{6}$ & 0.36 & $0.03 \pm 0.03$ & $0.01 \pm 0.02$ & $0.02 \pm 0.01$ & $0.05 \pm 0.22$ \\
\hline $\mathrm{C}_{8} \mathrm{H}_{9} \mathrm{NO}_{6}$ & 0.25 & $0.03 \pm 0.03$ & $0.01 \pm 0.02$ & $0.02 \pm 0.01$ & $0.08 \pm 0.92$ \\
\hline \multicolumn{6}{|l|}{ Di-NPs } \\
\hline $\mathrm{C}_{6} \mathrm{H}_{4} \mathrm{~N}_{2} \mathrm{O}_{5}$ & 21.1 & $2.5 \pm 2.5$ & $0.7 \pm 0.7$ & $2.2 \pm 1.7$ & $3.5 \pm 3.0$ \\
\hline $\mathrm{C}_{7} \mathrm{H}_{6} \mathrm{~N}_{2} \mathrm{O}_{5}$ & 4.5 & $0.8 \pm 0.7$ & $0.3 \pm 0.2$ & $0.8 \pm 0.7$ & $1.0 \pm 0.7$ \\
\hline $\mathrm{C}_{8} \mathrm{H}_{8} \mathrm{~N}_{2} \mathrm{O}_{5}$ & 2.56 & $0.21 \pm 0.31$ & $0.02 \pm 0.02$ & $0.10 \pm 0.19$ & $0.39 \pm 0.5$ \\
\hline $\mathrm{C}_{7} \mathrm{H}_{6} \mathrm{~N}_{2} \mathrm{O}_{6}$ & 0.54 & $0.07 \pm 0.05$ & $0.03 \pm 0.04$ & $0.06 \pm 0.04$ & $0.11 \pm 0.63$ \\
\hline \multicolumn{6}{|l|}{ Cl-NPs } \\
\hline $\mathrm{C}_{6} \mathrm{H}_{4} \mathrm{NO}_{3} \mathrm{Cl}$ & 1.19 & $0.22 \pm 0.19$ & $0.06 \pm 0.05$ & $0.20 \pm 0.13$ & $0.32 \pm 0.26$ \\
\hline $\mathrm{C}_{6} \mathrm{H}_{3} \mathrm{NO}_{3} \mathrm{Cl}_{2}$ & 0.88 & $0.07 \pm 0.06$ & $0.04 \pm 0.03$ & $0.08 \pm 0.05$ & $0.08 \pm 0.14$ \\
\hline
\end{tabular}

a: unit is ppt. 
Table S2. Average concentration of compounds input into model.

\begin{tabular}{|c|c|c|c|}
\hline compounds & concentration & compounds & concentration \\
\hline Benzene $^{a}$ & $1.3 \pm 0.5$ & $\mathrm{SO}_{2}{ }^{\mathrm{a}}$ & $1.3 \pm 0.6$ \\
\hline Toluene $^{\mathrm{a}}$ & $2.2 \pm 2.6$ & $\mathrm{O}_{3}{ }^{\mathrm{a}}$ & $59.2 \pm 14.9$ \\
\hline $\begin{array}{c}\text { Xylene and } \\
\text { ethylbenzene }\end{array}$ & $2 \pm 0.8$ & $\mathrm{CO}^{\mathrm{a}}$ & $292.4 \pm 75.4$ \\
\hline Propane $^{\mathrm{a}}$ & $1.5 \pm 0.6$ & $\mathrm{~N}_{2} \mathrm{O}_{5}{ }^{\mathrm{b}}$ & $40.1 \pm 67.2$ \\
\hline Propene $^{\mathrm{a}}$ & $0.1 \pm 0.1$ & $\mathrm{C}_{6} \mathrm{H}_{5} \mathrm{NO}_{3}{ }^{\mathrm{b}}$ & $15.9 \pm 12.7$ \\
\hline Butane $^{\text {a }}$ & $0.9 \pm 0.8$ & $\mathrm{C}_{7} \mathrm{H}_{7} \mathrm{NO}_{3}{ }^{\mathrm{b}}$ & $3.4 \pm 3.9$ \\
\hline Pentane $^{\mathrm{a}}$ & $0.4 \pm 0.2$ & $\mathrm{C}_{8} \mathrm{H}_{8} \mathrm{NO}_{3}{ }^{\mathrm{b}}$ & $0.5 \pm 0.6$ \\
\hline$i$-Butane ${ }^{\text {a }}$ & $0.6 \pm 0.3$ & $\mathrm{C}_{6} \mathrm{H}_{4} \mathrm{~N}_{2} \mathrm{O}_{5}{ }^{\mathrm{b}}$ & $2.4 \pm 1.8$ \\
\hline$i$-pentane ${ }^{\mathrm{a}}$ & $0.5 \pm 0.3$ & $\mathrm{C}_{7} \mathrm{H}_{6} \mathrm{~N}_{2} \mathrm{O}_{5}{ }^{\mathrm{b}}$ & $0.9 \pm 0.6$ \\
\hline Isoprene $^{\text {a }}$ & $1.7 \pm 0.5$ & $\mathrm{C}_{8} \mathrm{H}_{8} \mathrm{~N}_{2} \mathrm{O}_{5}{ }^{\mathrm{b}}$ & $0.1 \pm 0.2$ \\
\hline $\mathrm{NO}^{\mathrm{a}}$ & $0.3 \pm 0.7$ & Organic aerosol $^{\mathrm{c}}$ & $8.4 \pm 4.2$ \\
\hline $\mathrm{NO}_{2}{ }^{\mathrm{a}}$ & $2.9 \pm 2.8$ & Particle nitrate $^{\mathrm{c}}$ & $4.0 \pm 1.7$ \\
\hline
\end{tabular}

a: unit is ppbv;

b: unit is pptv;

c: unit is ug $/ \mathrm{m}^{3}$; 


\section{Reference}

1. Cheng, X.; Chen, Q.; Li, Y.; Huang, G.; Liu, Y.; Lu, S.; Zheng, Y.; Qiu, W.; Lu, K.; Qiu, X.; Bianchi, F.; Yan, C.; Yuan, B.; Shao, M.; Wang, Z.; Canagaratna, M. R.; Zhu, T.; Wu, Y.; Zeng, L. Secondary production of gaseous nitrated phenols in polluted urban environments. Environ. Sci. Technol. 2021, $55(8), 4410-4419$.

2. Troestl, J.; Chuang, W. K.; Gordon, H.; Heinritzi, M.; Yan, C.; Molteni, U.; Ahlm, L.; Frege, C.; Bianchi, F.; Wagner, R.; Simon, M.; Lehtipalo, K.; Williamson, C.; Craven, J. S.; Duplissy, J.; Adamov, A.; Almeida, J.; Bernhammer, A.-K.; Breitenlechner, M.; Brilke, S.; Dias, A.; Ehrhart, S.; Flagan, R. C.; Franchin, A.; Fuchs, C.; Guida, R.; Gysel, M.; Hansel, A.; Hoyle, C. R.; Jokinen, T.; Junninen, H.; Kangasluoma, J.; Keskinen, H.; Kim, J.; Krapf, M.; Kuerten, A.; Laaksonen, A.; Lawler, M.; Leiminger, M.; Mathot, S.; Moehler, O.; Nieminen, T.; Onnela, A.; Petaejae, T.; Piel, F. M.; Miettinen, P.; Rissanen, M. P.; Rondo, L.; Sarnela, N.; Schobesberger, S.; Sengupta, K.; Sipila, M.; Smith, J. N.; Steiner, G.; Tome, A.; Virtanen, A.; Wagner, A. C.; Weingartner, E.; Wimmer, D.; Winkler, P. M.; Ye, P.; Carslaw, K. S.; Curtius, J.; Dommen, J.; Kirkby, J.; Kulmala, M.; Riipinen, I.; Worsnop, D. R.; Donahue, N. M.; Baltensperger, U. The role of low-volatility organic compounds in initial particle growth in the atmosphere. Nature 2016, 533 (7604), 527-531.

3. Heinritzi, M.; Simon, M.; Steiner, G.; Wagner, A. C.; Kuerten, A.; Hansel, A.; Curtius, J. Characterization of the mass-dependent transmission efficiency of a CIMS. Atmos. Meas. Tech. 2016, $9(4), 1449-1460$.

4. Kuerten, A.; Rondo, L.; Ehrhart, S.; Curtius, J. Calibration of a chemical ionization mass spectrometer for the measurement of gaseous sulfuric acid. J. Phys. Chem. A 2012, 116 (24), 63756386.

5. Kirkby, J.; Duplissy, J.; Sengupta, K.; Frege, C.; Gordon, H.; Williamson, C.; Heinritzi, M.; Simon, M.; Yan, C.; Almeida, J.; Troestl, J.; Nieminen, T.; Ortega, I. K.; Wagner, R.; Adamov, A.; Amorim, A.; Bernhammer, A.-K.; Bianchi, F.; Breitenlechner, M.; Brilke, S.; Chen, X.; Craven, J.; Dias, A.; Ehrhart, S.; Flagan, R. C.; Franchin, A.; Fuchs, C.; Guida, R.; Hakala, J.; Hoyle, C. R.; Jokinen, T.; Junninen, H.; Kangasluoma, J.; Kim, J.; Krapf, M.; Kuerten, A.; Laaksonen, A.; Lehtipalo, K.; Makhmutov, V.; Mathot, S.; Molteni, U.; Onnela, A.; Peraekylae, O.; Piel, F.; Petaejae, T.; Praplan, A. P.; Pringle, K.; Rap, A.; Richards, N. A. D.; Riipinen, I.; Rissanen, M. P.; Rondo, L.; Sarnela, N.; 
Schobesberger, S.; Scott, C. E.; Seinfeld, J. H.; Sipilae, M.; Steiner, G.; Stozhkov, Y.; Stratmann, F.; Tome, A.; Virtanen, A.; Vogel, A. L.; Wagner, A. C.; Wagner, P. E.; Weingartner, E.; Wimmer, D.; Winkler, P. M.; Ye, P.; Zhang, X.; Hansel, A.; Dommen, J.; Donahue, N. M.; Worsnop, D. R.; Baltensperger, U.; Kulmala, M.; Carslaw, K. S.; Curtius, J. Ion-induced nucleation of pure biogenic particles. Nature 2016, 533 (7604), 521-526.

6. Pu, W.; Zou, Z.; Wang, W.; Tanner, D.; Wang, Z.; Wang, T. Development of a chemical ionization mass spectrometry system for measurement of atmospheric $\mathrm{OH}$ radical. Atmos. Meas. Tech. Discuss. 2020.

7. Li, M.; Wang, X.; Lu, C.; Li, R.; Zhang, J.; Dong, S.; Yang, L.; Xue, L.; Chen, J.; Wang, W. Nitrated phenols and the phenolic precursors in the atmosphere in urban Jinan, China. Sci. Total Environ. 2020, 714, 136760.

8. Chow, K. S.; Huang, X. H. H.; Yu, J. Z. Quantification of nitroaromatic compounds in atmospheric fine particulate matter in Hong Kong over 3 years: field measurement evidence for secondary formation derived from biomass burning emissions. Environ. Chem. 2016, 13 (4), 665.

9. Harrison, M. A. J.; Barra, S.; Borghesi, D.; Vione, D.; Arsene, C.; Iulian Olariu, R. Nitrated phenols in the atmosphere: a review. Atmos. Environ. 2005, 39 (2), 231-248.

10. Yuan, B.; Liggio, J.; Wentzell, J.; Li, S.-M.; Stark, H.; Roberts, J. M.; Gilman, J.; Lerner, B.; Warneke, C.; Li, R.; Leithead, A.; Osthoff, H. D.; Wild, R.; Brown, S. S.; de Gouw, J. A. Secondary formation of nitrated phenols: insights from observations during the Uintah Basin Winter Ozone Study (UBWOS) 2014. Atmos. Chem. Phys. 2016, 16 (4), 2139-2153.

11. Mohr, C.; Lopez-Hilfiker, F. D.; Zotter, P.; Prevot, A. S.; Xu, L.; Ng, N. L.; Herndon, S. C.; Williams, L. R.; Franklin, J. P.; Zahniser, M. S.; Worsnop, D. R.; Knighton, W. B.; Aiken, A. C.; Gorkowski, K. J.; Dubey, M. K.; Allan, J. D.; Thornton, J. A. Contribution of nitrated phenols to wood burning brown carbon light absorption in Detling, United Kingdom during winter time. Environ. Sci. Technol. 2013, 47 (12), 6316-6324.

12. Gaston, C. J.; Lopez-Hilfiker, F. D.; Whybrew, L. E.; Hadley, O.; McNair, F.; Gao, H.; Jaffe, D. A.; Thornton, J. A. Online molecular characterization of fine particulate matter in Port Angeles, WA: Evidence for a major impact from residential wood smoke. Atmos. Environ. 2016, 138, 99-107.

13. Song, K.; Guo, S.; Wang, H.; Yu, Y.; Wang, H.; Tang, R.; Xia, S.; Gong, Y.; Wan, Z.; Lv, D.; Tan, R.; Zhu, W.; Shen, R.; Li, X.; Yu, X.; Chen, S.; Zeng, L.; Huang, X. Measurement report: Online 
measurement of gas-phase nitrated phenols utilizing a CI-LToF-MS: primary sources and secondary formation. Atmos. Chem. Phys. 2021, 21 (10), 7917-7932.

14. Salvador, C. M. G.; Tang, R.; Priestley, M.; Li, L.; Tsiligiannis, E.; Le Breton, M.; Zhu, W.; Zeng, L.; Wang, H.; Yu, Y.; Hu, M.; Guo, S.; Hallquist, M. Ambient nitro-aromatic compounds - biomass burning versus secondary formation in rural China. Atmos. Chem. Phys. 2021, 21 (3), 1389-1406.

15. Palm, B. B.; Peng, Q.; Fredrickson, C. D.; Lee, B. H.; Garofalo, L. A.; Pothier, M. A.; Kreidenweis, S. M.; Farmer, D. K.; Pokhrel, R. P.; Shen, Y.; Murphy, S. M.; Permar, W.; Hu, L.; Campos, T. L.; Hall, S. R.; Ullmann, K.; Zhang, X.; Flocke, F.; Fischer, E. V.; Thornton, J. A. Quantification of organic aerosol and brown carbon evolution in fresh wildfire plumes. Proc. Natl. Acad. Sci. U. S. A. 2020, 117 (47), 29469-29477.

16. Jenkin, M. E.; Young, J. C.; Rickard, A. R. The MCM v3.3.1 degradation scheme for isoprene. Atmos. Chem. Phys. 2015, 15 (20), 11433-11459.

17. Saunders, S. M.; Jenkin, M. E.; Derwent, R. G.; Pilling, M. J. Protocol for the development of the Master ChemicalMechanism, MCMv3 (Part A): Tropospheric degradation of non-aromatic volatile organic compounds. Atmos. Chem. Phys. 2003, 3, 161-180.

18. Jenkin, M. E.; Saunders, S. M.; Wagner, V.; Pilling, M. J. Protocol for the development of the Master ChemicalMechanism, MCMv3 (Part B): Tropospheric degradation of aromatic volatile organic compounds. Atmos. Chem. Phys. 2003, 3, 181-193.

19. Bloss, C.; Wagner, V.; Jenkin, M. E.; Volkamer, R.; Bloss, W. J.; Lee, J. D.; Heard, D. E.; Wirtz, K.; Martin-Reviejo, M.; Rea, G.; Wenger, J. C.; Pilling, M. J. Development of a detailed chemical mechanism (MCMv3.1) for the atmospheric oxidation of aromatic hydrocarbons. Atmos. Chem. Phys. 2005, 5, 641-664.

20. Sangwan, M.; Zhu, L. Absorption cross sections of 2-nitrophenol in the 295-400 $\mathrm{nm}$ region and photolysis of 2-nitrophenol at 308 and $351 \mathrm{~nm}$. J. Phys. Chem. A 2016, 120 (50), 9958-9967.

21. Sangwan, M.; Zhu, L. Role of methyl-2-nitrophenol photolysis as a potential source of OH radicals in the polluted atmosphere: Implications from laboratory investigation. J. Phys. Chem. A 2018, 122 (7), 1861-1872.

22. Bardini, P. Atmospheric chemistry of dimethylphenols \& nitrophenols. Ph.D. thesis, University College Cork, 2006.

23. Bejan, I.; Barnes, I.; Olariu, R.; Zhou, S.; Wiesen, P.; Benter, T. Investigations on the gas-phase 
photolysis and $\mathrm{OH}$ radical kinetics of methyl-2-nitrophenols. Phys. Chem. Chem. Phys. 2007, 9 (42), 5686-5692.

24. Hinrichs, R. Z.; Buczek, P.; Trivedi, J. J. Solar Absorption by Aerosol-Bound Nitrophenols Compared to Aqueous and Gaseous Nitrophenols. Environ. Sci. Technol. 2016, 50 (11), 5661-5667. 25. Xue, L. K.; Wang, T.; Gao, J.; Ding, A. J.; Zhou, X. H.; Blake, D. R.; Wang, X. F.; Saunders, S. M.; Fan, S. J.; Zuo, H. C.; Zhang, Q. Z.; Wang, W. X. Ground-level ozone in four Chinese cities: precursors, regional transport and heterogeneous processes. Atmos. Chem. Phys. 2014, 14 (23), $13175-$ 13188.

26. Johnson, D.; Jenkin, M. E.; Wirtz, K.; Martin-Reviejo, M. Simulating the formation of secondary organic aerosol from the photooxidation of aromatic hydrocarbons. Environ. Chem . 2005, 2 (1), 35. 27. Barley, M. H.; McFiggans, G. The critical assessment of vapour pressure estimation methods for use in modelling the formation of atmospheric organic aerosol. Atmos. Chem. Phys. 2010, 10, 749767.

28. O'Meara, S.; Booth, A. M.; Barley, M. H.; Topping, D.; McFiggans, G. An assessment of vapour pressure estimation methods. Phys. Chem. Chem. Phys. 2014, 16 (36), 19453-69.

29. Stein, S. E.; Brown, R. L. Estimation of normal boiling points from group contributions. J. Chem. Inf. Comp. Sci. 1994, 34 (3), 581-587.

30. Nannoolal, Y.; Rarey, J.; Ramjugernath, D. Estimation of pure component properties - Part 3. Estimation of the vapor pressure of non-electrolyte organic compounds via group contributions and group interactions. Fluid Phase Equilib. 2008, 269 (1-2), 117-133.

31. Fu, X.; Wang, T.; Zhang, L.; Li, Q.; Wang, Z.; Xia, M.; Yun, H.; Wang, W.; Yu, C.; Yue, D.; Zhou, Y.; Zheng, J.; Han, R. The significant contribution of HONO to secondary pollutants during a severe winter pollution event in southern China. Atmos. Chem. Phys. 2019, 19 (1), 1-14. 